\title{
Mechanisms involved in IL-15 superagonist enhancement of anti-PD-L1 therapy
}

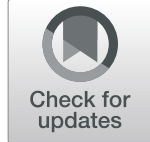

Karin M. Knudson ${ }^{1}$, Kristin C. Hicks ${ }^{1}$, Sarah Alter ${ }^{2}$, Jeffrey Schlom ${ }^{1 *+} \mathbb{D}$ and Sofia R. Gameiro ${ }^{1+}$

\begin{abstract}
Background: Immunotherapy targeting PD-1/PD-L1 fails to induce clinical responses in most patients with solid cancers. N-803, formerly ALT-803, is an IL-15 superagonist mutant and dimeric IL-15RaSushi-Fc fusion protein complex that enhances $\mathrm{CD} 8^{+} \mathrm{T}$ and $\mathrm{NK}$ cell expansion and function and exhibits anti-tumor efficacy in preclinical models. Previous in vitro studies have shown that IL-15 increases PD-L1 expression, a negative regulator of CD8 ${ }^{+} \mathrm{T}$ and NK cell function. Most reported preclinical studies administered N-803 intraperitoneally not subcutaneously, the current clinical route of administration. N-803 is now being evaluated clinically in combination with PD-1/PD-L1 inhibitors. However, the mechanism of action has not been fully elucidated. Here, we examined the antitumor efficacy and immunomodulatory effects of combining N-803 with an anti-PD-L1 antibody in preclinical models of solid carcinomas refractory to anti-PD-L1 or N-803.
\end{abstract}

Methods: Subcutaneous N-803 and an anti-PD-L1 monoclonal antibody were administered as monotherapy or in combination to 4T1 triple negative breast and MC38-CEA colon tumor-bearing mice. Anti-tumor efficacy was evaluated, and a comprehensive analysis of the immune-mediated effects of each therapy was performed on the primary tumor, lung as a site of metastasis, and spleen.

Results: We demonstrate that N-803 treatment increased PD-L1 expression on immune cells in vivo, supporting the combination of N-803 and anti-PD-L1. N-803 plus anti-PD-L1 was well-tolerated, reduced 4T1 lung metastasis and MC38-CEA tumor burden, and increased survival as compared to N-803 and anti-PD-L1 monotherapies. Efficacy of the combination therapy was dependent on both $C D 8^{+} \mathrm{T}$ and NK cells and was associated with increased numbers of these activated immune cells in the lung and spleen. Most alterations to NK and CD8 $8^{+} T$ cell phenotype and number were driven by $\mathrm{N}-803$. However, the addition of anti-PD-L1 to N-803 significantly enhanced $C D 8^{+} \mathrm{T}$ cell effector function versus N-803 and anti-PD-L1 monotherapies, as indicated by increased Granzyme B and IFNy production, at the site of metastasis and in the periphery. Increased $C D 8^{+} T$ cell effector function correlated with higher serum IFNy levels, without related toxicities, and enhanced anti-tumor efficacy of the N-803 plus anti-PD-L1 combination versus either monotherapy.

Conclusions: We provide novel insight into the mechanism of action of N-803 plus anti-PD-L1 combination and offer preclinical proof of concept supporting clinical use of $\mathrm{N}-803$ in combination with checkpoint inhibitors, including for patients non- and/or minimally responsive to either monotherapy.

Keywords: PD-L1, ALT-803, N-803, Tumor microenvironment

\footnotetext{
* Correspondence: js141c@nih.gov

${ }^{\dagger}$ Jeffrey Schlom and Sofia R. Gameiro contributed equally to this work.

'Laboratory of Tumor Immunology and Biology, Center for Cancer Research,

National Cancer Institute, National Institutes of Health, Bethesda, MD, USA

Full list of author information is available at the end of the article
}

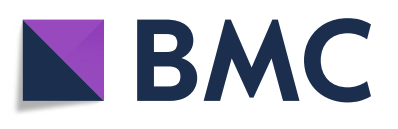

(c) The Author(s). 2019 Open Access This article is distributed under the terms of the Creative Commons Attribution 4.0 International License (http://creativecommons.org/licenses/by/4.0/), which permits unrestricted use, distribution, and

reproduction in any medium, provided you give appropriate credit to the original author(s) and the source, provide a link to the Creative Commons license, and indicate if changes were made. The Creative Commons Public Domain Dedication waiver (http://creativecommons.org/publicdomain/zero/1.0/) applies to the data made available in this article, unless otherwise stated. 


\section{Introduction}

The gamma $\mathrm{c}(\gamma \mathrm{c})$ cytokine interleukin (IL)-15 is a promising immunotherapy. IL-15 promotes $\mathrm{CD}^{+} \mathrm{T}$ and natural killer (NK) cell activation, proliferation, cytotoxicity, and survival [1]. N-803, previously known as ALT-803, is an IL-15 superagonist mutant complexed to a dimeric IL- $15 R \alpha$ Sushi-Fc fusion protein [2-4]. This fully humanized complex enhances IL-15 biological activity and stability in vivo [2-4] and promotes greater activation of $\mathrm{CD}^{+} \mathrm{T}$ cells and NK cells than recombinant IL-15 (rIL-15) with less toxicity [5-8]. N-803 was initially delivered intravenously (i.v.) with no observed dose limiting toxicities (DLTs); however, subcutaneous (s.c.) delivery of N-803 attenuated many adverse events, increased serum persistence, and expanded the number of circulating $\mathrm{NK}$ and $\mathrm{CD}^{+} \mathrm{T}$ cells as compared to systemic administration [7]. Consequentially, N-803 is now administered subcutaneously in the clinic. While preclinical studies with N-803 have demonstrated antitumor efficacy against multiple murine solid carcinomas, including breast [9], colon [5], and glioblastoma [10], these studies administered N-803 systemically via intraperitoneal (i.p.) injection. Pharmacokinetics, biodistribution, immune stimulation, and efficacy of s.c. versus i.v. administration were previously evaluated in a 5 T33 tumor model [11], but the efficacy of s.c.-administered $\mathrm{N}-803$ on murine solid tumors and the mechanism of action have not been investigated.

In most murine solid carcinoma studies, N-803 monotherapy was not curative $[5,9,10]$. This may be due to immune suppression in the tumor microenvironment (TME), which includes the expression of checkpoint inhibitor molecules such as programmed cell death ligand-1 (PD-L1). Aberrant overexpression of PD-L1, which inhibits immune cell maturation, proliferation, and effector function [12,13], is observed in numerous malignancies and is associated with poor clinical outcome $[14,15]$. Antibodies blocking PD-L1 or programmed cell death-1 (PD-1) have increased patient survival in carcinomas with significant mutational burden such as melanoma [16, 17], lung $[18,19]$, and bladder cancers [20, 21]. However, most patients with solid carcinomas fail to respond to PD-1/PD-L1 blockade, including those with triple-negative (TN) breast and colon carcinomas [12]. Thus, there is an unmet need to develop combination therapies that improve clinical benefit for these patients.

One study recently demonstrated that rIL-15 induces PD-L1 expression in vitro on immune cells [22], providing further rationale for the combination of N-803 and PD-L1-targeted agents. The effect of N-803 on PD-L1 expression in vivo has not been reported. Preliminary studies of N-803 (i.p.) combination with anti-PD-1 $(\alpha \mathrm{PD}-1)$ or anti-PD-L1 ( $\alpha$ PD-L1) monoclonal antibodies have shown mixed results in murine solid carcinoma models $[9,10]$. However, a recent Phase $1 \mathrm{~b}$ clinical trial reported that the combination of $\mathrm{N}-803$ with the $\alpha \mathrm{PD}-1$ antibody nivolumab in metastatic non-small cell lung cancer (NSCLC) patients was well-tolerated, and 29\% of patients exhibited an objective response [23]. Of note, the addition of $\mathrm{N}-803$ promoted objective responses in $3 / 11(27 \%)$ of patients previously treated with PD-1 therapy [23], which suggests this agent may aid in overcoming acquired resistance to checkpoint blockade. A comprehensive analysis of the immune mechanisms of this combination has not been reported preclinically or clinically.

Here, for the first time, we describe the anti-tumor efficacy of subcutaneously administered IL-15 superagonist N-803 (previously known as ALT-803) in combination with an $\alpha$ PD-L1 monoclonal antibody in murine TN breast and colon carcinoma models. Furthermore, we report the immune-mediated mechanism of action of N-803 plus $\alpha$ PD-L1 combination therapy.

\section{Materials and methods Reagents}

N-803 was generously provided by NantBioScience under a Cooperative Research and Development Agreement with the National Cancer Institute. $\alpha$ PD-L1 (10F.9G2), CD8 (2.43), and CD4 (GK1.5) depletion antibodies were from BioXcell. The NK depletion antibody (anti-asialo-GM1) was from Wako Chemicals.

\section{Mice}

Six- to 10-week old female Balb/c and C57BL/6 mice transgenic for carcinoembryonic antigen (CEA) (designated C57BL/6-CEA) [24] were obtained from the NCI Frederick Cancer Research Facility and maintained under specific pathogen-free conditions in accordance with the Association for Assessment and Accreditation of Laboratory Animal Care (AAALAC) guidelines. All studies were approved by the NIH Intramural Animal Care and Use Committee (IACUC).

\section{Murine tumor cell lines and tumor studies}

4T1 TN breast carcinoma and Yac-1 lymphoma cells were obtained from American Type Culture Collection (ATCC). MC38 colon carcinoma cells expressing human CEA (MC38-CEA) were generated as previously reported [25]. All cell lines were cultured according to providers' instructions [25], determined as mycoplasma free by MycoAlert Mycoplasma Detection Kit (Lonza), and used at low passage number.

For anti-tumor studies, $4 \mathrm{~T} 1$ tumor cells $\left(5 \times 10^{4}\right.$, s.c. $)$ were orthotopically implanted into the mammary fat pad of female Balb/c mice on day 0 . In select studies, the primary tumor was surgically excised at day 15. MC38-CEA 
$\left(5 \times 10^{5}\right.$, s.c.) tumor cells were implanted into the right flank of female C57BL/6-CEA mice. Tumors were measured biweekly using calipers, and volumes were determined as (length ${ }^{2} \times$ width)/2. Mice were randomized based on tumor size and treatment initiated when tumors reached $50-100 \mathrm{~mm}^{3}$. Mice received three doses of $200 \mu \mathrm{g}$ $\alpha$ PD-L1 i.p. $(10 \mathrm{mg} / \mathrm{kg})$, a clinically relevant dose [21], and/or two doses of $\mathrm{N}-803$ s.c. at $1 \mu \mathrm{g}$ [9]. Quantification of $4 \mathrm{~T} 1$ lung metastasis was performed as previously described $[26,27]$.

\section{Depletion studies}

CD4 or CD8 depletion antibodies (100 $\mu$ g, i.p.) were administered on days 6,7 , and 8 post-tumor implant followed by once weekly. NK depletion antibody $(25 \mu \mathrm{l}$ in $100 \mu \mathrm{l} \mathrm{PBS}$, i.p.) was administered on days 6 and 8 post-tumor implant, then every 3 days. Due to toxicity, depletions were terminated after day 19 . Weekly depletion efficiency was determined in the blood $(\sim 50 \mu \mathrm{l})$ by flow cytometry. Percent reduction of $\mathrm{CD}^{+} \mathrm{T}, \mathrm{NK}$, or $\mathrm{CD}^{+}{ }^{+} \mathrm{T}$ cells was determined versus undepleted $\mathrm{N}-803$ $+\alpha$ PD-L1-treated mice (set to $0 \%$ ).

\section{Isolation of immune cells}

Homogenized and filtered spleens underwent ACK lysis. Tumors and lungs were digested using the gentleMACS Dissociator according to the manufacturer's instructions (Miltenyi Biotec). Tumor-infiltrating lymphocytes (TILs) and lung-resident immune cells were enriched using a 44\%/67\% Percoll Plus (GE Healthcare) gradient. Cell counts were performed using 123count eBeads (ThermoFisher Scientific).

\section{Flow cytometry and antibodies}

Antibody labeling of cells for flow cytometry $\left(1-10 \times 10^{6}\right.$ immune cells) was performed using the BD Cytofix/ Cytoperm Kit (BD Biosciences) according to the manufacturer's instructions. Antibodies (Additional file 1: Table S1) and matched isotypes were obtained from the listed manufacturers. Live/Dead Fixable Dead Cell Stain was from Invitrogen. Flow cytometry $\left(\geq 1 \times 10^{5}\right.$ events $)$ was performed on a BD FACSVerse or LSRFortessa flow cytometer (Becton Dickinson) and analyzed with FlowJo FACS Analysis Software v9.9.6 (Treestar). Cell populations were identified as listed (Additional file 1: Table S2). Expression of phenotypic proteins was determined by subtracting the respective isotype, set between 1 and $5 \%$ of the population.

\section{Discrimination of immune cells in lung parenchyma versus vasculature}

To discriminate the presence of lung parenchymal versus intravascular immune cells, mice were injected with

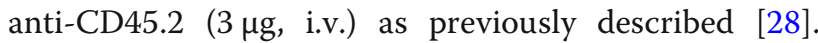
See Additional file 1: Figure S1.

\section{$\mathrm{CD8}^{+} \mathrm{T}$ cell and NK cell restimulation}

Isolated spleen, lung, and tumor immune cells were stimulated for $4 \mathrm{~h}$ in the presence of $2 \mu \mathrm{g} / \mathrm{ml}$ GolgiPlug (BD Biosciences) with nothing, for the $\mathrm{CD}^{+} \mathrm{T}$ cell restimulation $1 \mu \mathrm{g} / \mathrm{ml} \alpha \mathrm{CD} 3$ (2C11, BD Biosciences) + $1 \mu \mathrm{g} / \mathrm{ml} \alpha \mathrm{CD} 28$ (37.51, BD Biosciences), or for the NK cell restimulation $50 \mathrm{ng} / \mathrm{ml}$ PMA (Sigma) $+500 \mathrm{ng} / \mathrm{ml}$ ionomycin (Sigma). Frequencies of stimulated IFN $\gamma^{+}$ and/or $\mathrm{TNF}^{+}$cells were calculated by subtracting the non-stimulated controls.

\section{NK cell cytotoxicity assay}

Purified splenic NK cells (NK Cell Isolation Kit, Miltenyi Biotec) were co-cultured for $18 \mathrm{~h}$ with ${ }^{111}$ In-labeled Yac-1 target cells at a 100:1 effector-to-target ratio. Supernatant ${ }^{111}$ In radioactivity was quantified (WIZARD ${ }^{2}$ $\gamma$ counter, PerkinElmer), and percent lysis was determined as previously described [9].

\section{Detection and quantification of serum cytokines}

Serum cytokines were quantified using the V-PLEX Proinflammatory Panel I Mouse Kit and MESO QuickPlex SQ 120 (Meso Scale Diagnostics, LLC). Limits of detection were: IFNy: $0.04 \mathrm{pg} / \mathrm{ml}$, IL-6: $0.61 \mathrm{pg} / \mathrm{ml}$, IL-10: $0.95 \mathrm{pg} / \mathrm{ml}$, TNF $\alpha$ : $0.13 \mathrm{pg} / \mathrm{ml}$.

\section{Statistics}

Statistical analyses were performed in Prism 7.0a (GraphPad Software). Unless otherwise stated, data presented in bar graphs or scatter plots were analyzed using one-way ANOVA with Tukey's multiple comparisons. Two-way ordinary ANOVA was used to analyze tumor growth curves. Survival was analyzed using Log-rank (Mantel-Cox) test. Outliers were identified using ROUT test. Statistical significance was set at $p<0.05 .{ }^{*} p<0.05,{ }^{* * *} p<0.01$, ${ }^{* * * * *} p<0.001$.

\section{Results}

$\mathrm{N}-803$ increases PD-L1 expression on hematopoietic cells $\mathrm{N}-803$ reduces tumor burden in multiple murine solid carcinoma models. However, in many cases, it was not curative $[5,9]$. It has been shown that IL-15 increases PD-L1 expression on immune cells in vitro [22], but the effect of rIL-15 or N-803 on PD-L1 expression in vivo has not been reported. Thus, it is possible that N-803 enhances PD-L1 expression in tumor-bearing mice, reducing the efficacy of $\mathrm{N}-803$ monotherapy. Indeed, s.c.-delivered N-803 enhanced PD-L1 expression on $\mathrm{CD} 45^{+}$hematopoietic cells in the primary tumor, lung parenchyma and vasculature, and spleen of 4T1 TN breast tumor-bearing mice (Fig. 1a). In addition, 
A

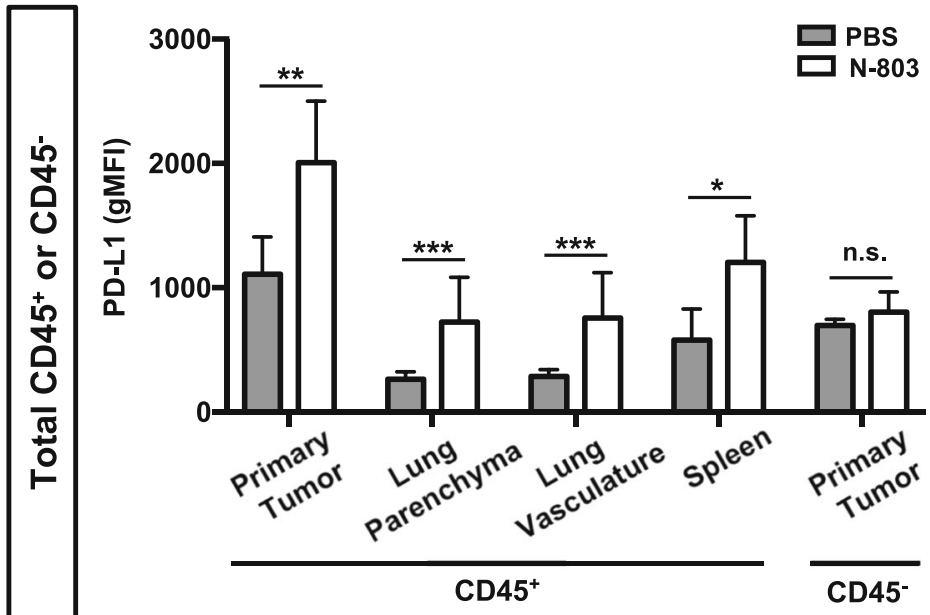

B

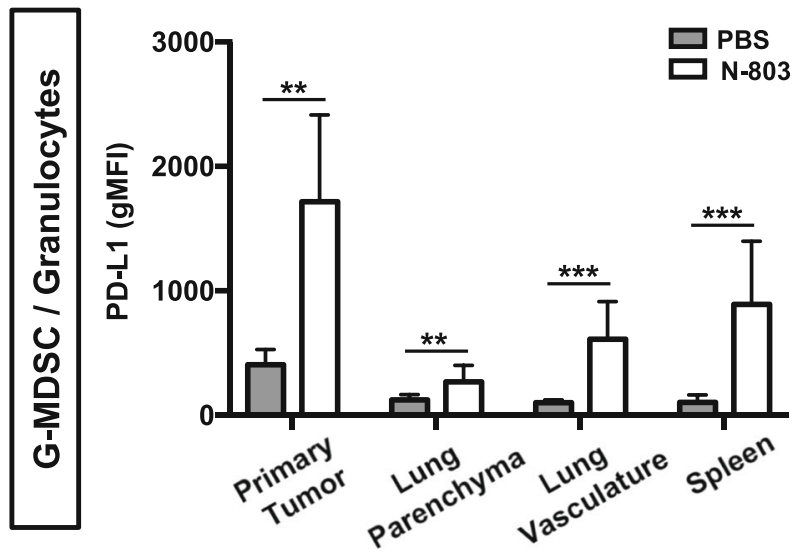

C

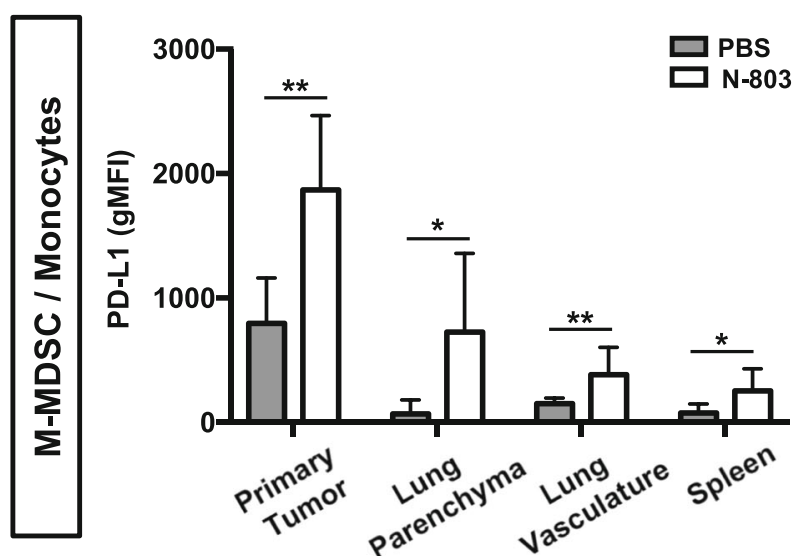

Fig. 1 N-803 treatment increases PD-L1 expression on total CD45+ cells and MDSC populations in the primary tumor, lung, and spleen. $5 \times 10^{4}$ $4 \mathrm{~T} 1$ tumor cells were orthotopically implanted into female Balb/c mice. When tumor volumes reached $\sim 50 \mathrm{~mm}^{3}$, mice were treated at days 9 and 13 with $1 \mu \mathrm{g} \mathrm{N}-803$ (s.c.). Twenty-four hours after the last treatment, PD-L1 expression (geometric mean fluorescence intensity (gMFI)) in the primary tumor, lung parenchyma and vasculature, and spleen was determined by flow cytometry on total CD45 $5^{+}$or CD45 cells (a), G-MDSC/ Granulocytes (b), or M-MDSC/Monocytes (c). Graphs show mean \pm SD. Data combined from 2 independent experiments, $n=5$ mice/group per experiment 
granulocytic myeloid derived suppressor cell (G-MDSC)/ granulocyte and monocytic MDSC (M-MDSC)/monocyte populations had increased expression of PD-L1 (Fig. 1b,c). PD-L1 expression on non-hematopoietic, tumor-associated $\mathrm{CD}^{-} 5^{-}$cells did not change (Fig. 1a). These results demonstrate that N-803 increases PD-L1 expression on immune cells in vivo and provide the rationale for combining N-803 with a PD-L1-targeted antibody for the treatment of solid carcinomas.

$\mathrm{N}-803$ + aPD-L1 combination decreases tumor burden and improves overall survival in murine breast and colon carcinoma models

Given the increase in PD-L1 expression upon N-803 treatment, we examined the combination of $\mathrm{N}-803$ with an $\alpha$ PD-L1 monoclonal antibody for anti-tumor efficacy. Successful combination of these agents has not been reported [9], and previous studies using N-803 with checkpoint blockade did not use subcutaneous delivery of $\mathrm{N}-803$, the route of administration used in the clinic [7, 8, 23].

First, we examined the efficacy of N-803 plus $\alpha$ PD-L1 $(\mathrm{N}-803+\alpha \mathrm{PD}-\mathrm{L} 1)$ combination therapy in mice bearing 4T1 TN breast tumors, which are highly metastatic [29] and have previously demonstrated resistance to $\alpha$ PD-L1 monotherapy [30]. Initial studies determined that $1 \mu \mathrm{g}$ s.c. N-803 in combination with $200 \mu \mathrm{g}(10 \mathrm{mg} / \mathrm{kg})$ $\alpha \mathrm{PD}-\mathrm{L} 1$, a clinically relevant dose [21], promoted greater reduction in lung tumor burden than higher doses of N-803 (Additional file 1: Figure S2A-C). Furthermore, significant reduction in body weight was observed after treatment with higher doses of N-803 (Additional file 1: Figure S2D-E). Thus, all studies were performed using $1 \mu \mathrm{g} \mathrm{N}-803$ s.c. plus $200 \mu \mathrm{g} \alpha \mathrm{PD}-\mathrm{L} 1$ i.p.

In the adjuvant setting, without resection of the primary tumor, N-803+ $\alpha \mathrm{PD}-\mathrm{L} 1$ reduced primary $4 \mathrm{~T} 1$ tumor growth (Fig. 2a) and decreased the number of lung metastases by $78 \%$ compared to phosphate buffered saline (PBS) treatment (Fig. 2b,c). Neither $\alpha$ PD-L1 nor N-803 monotherapy significantly reduced primary or lung tumor burden compared to PBS treatment (Fig. 2a-c). Combination therapy further reduced lung metastasis burden by 75 and $62 \%$ compared to $\alpha$ PD-L1 and N-803 monotherapies, respectively (Fig. 2c).

Most breast cancer patients have their primary lesion surgically removed. To mimic the clinical regimen, we surgically resected primary 4T1 tumors 15 days after implant. None of the treatments reduced primary tumor growth prior to resection (Fig. $2 \mathrm{~d}$ ). $\alpha$ PD-L1 monotherapy did not affect 4T1 lung metastasis, but N-803 monotherapy significantly reduced lung tumor burden by $49 \%$ as compared to PBS treatment (Fig. 2e,f). The addition of $\alpha \mathrm{PD}-\mathrm{L} 1$ to $\mathrm{N}-803$ improved this response and promoted a $67 \%$ reduction in lung metastasis burden versus
PBS (Fig. 2e,f). The observed decrease in lung metastasis with $\mathrm{N}-803$ monotherapy and $\mathrm{N}-803+\alpha \mathrm{PD}-\mathrm{L} 1$ correlated with significant increases in median overall survival (mOS) as compared to PBS- and $\alpha$ PD-L1-treated mice (Fig. 2g). N-803 and N-803 $+\alpha$ PD-L1 increased survival by 38 and $62 \%$ versus PBS treatment, respectively (Fig. 2g).

We also examined the anti-tumor efficacy of N-803 $+\alpha$ PD-L1 therapy in the aggressive murine MC38-CEA colon carcinoma model. N-803 $+\alpha$ PD-L1 significantly reduced tumor burden compared to $\mathrm{PBS}$ treatment, with $43 \%$ of mice cured (Additional file 1: Figure S3A,B) and an $83 \%$ increase in mOS (Additional file 1: Figure S3C). $\mathrm{N}-803$ did not reduce tumor burden in this model. However, $\alpha$ PD-L1 monotherapy cured $12.5 \%$ of mice but did not significantly improve mOS (Additional file 1: Figure S3A-C). $\alpha$ PD-L1 and N-803 $+\alpha$ PD-L1 therapies promoted long-term immunity as MC38-CEA rechallenge of cured mice did not induce palpable tumors (Additional file 1: Figure S3D,E).

All together, these results demonstrate for the first time that subcutaneously delivered N-803 in combination with $\alpha$ PD-L1 decreases tumor burden and improves overall survival in multiple murine solid carcinoma models. Importantly, $\mathrm{N}-803+\alpha \mathrm{PD}-\mathrm{L} 1$ combination increases anti-tumor efficacy versus both N-803 and $\alpha$ PD-L1 monotherapies.

\section{Anti-tumor efficacy of $\mathrm{N}-803+$ aPD-L1 therapy is dependent on $\mathrm{NK}$ and $\mathrm{CD}^{+} \mathrm{T}$ cells}

To begin elucidating the mechanism by which N-803 $+\alpha \mathrm{PD}-\mathrm{L} 1$ mediated anti-tumor efficacy, we first determined the immune cells required to reduce tumor burden in 4T1 tumor-bearing mice. As $\mathrm{CD}^{+} \mathrm{T}$ and $\mathrm{NK}$ cells were necessary for the anti-tumor efficacy of N-803 monotherapy in the 4T1 model [9], we performed $\mathrm{CD}^{+}$ $\mathrm{T}$ cell and NK cell depletions in N-803+ $\alpha$ PD-L1treated mice. Vascular $\mathrm{CD}^{+} \mathrm{T}$ cells and NK cells were depleted by $\sim 98 \%$ and $\sim 90 \%$, respectively, over the first 3 weeks of the experiment (Additional file 1: Figure S4A-C). N-803 + $\alpha$ PD-L1 significantly reduced primary tumor growth and lung metastasis versus PBS treatment (Fig. 3a-c). While $\mathrm{CD}^{+} \mathrm{T}$ cell depletion did not significantly increase the number of lung metastases versus $\mathrm{N}-803+\alpha \mathrm{PD}-\mathrm{L} 1$ therapy, it did increase mean lung tumor burden by $175 \%$ (Fig. 3b,c). Furthermore, there was no significant difference in the number of lung metastases in CD8-depleted mice compared to PBS treatment (Fig. 3b,c). The NK cell depletion, on the other hand, significantly increased lung tumor burden by $589 \%$ versus N-803 + $\alpha$ PD-L1 therapy (Fig. 3b,c). Depletion of both $\mathrm{CD}^{+} \mathrm{T}$ cells and NK cells mimicked the results seen with NK cell depletion (Fig. 3a-c). Of note, 99\% depletion of $\mathrm{CD}^{+} \mathrm{T}$ cells had no effect on the 


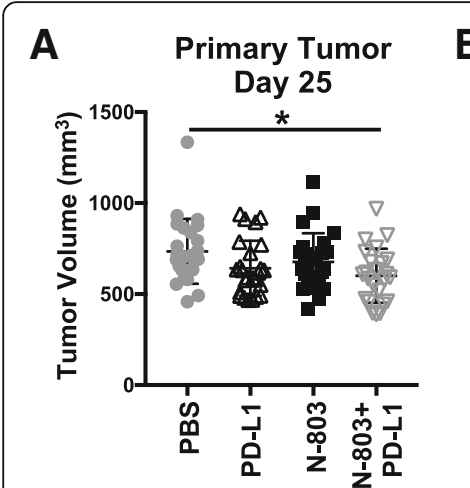

D

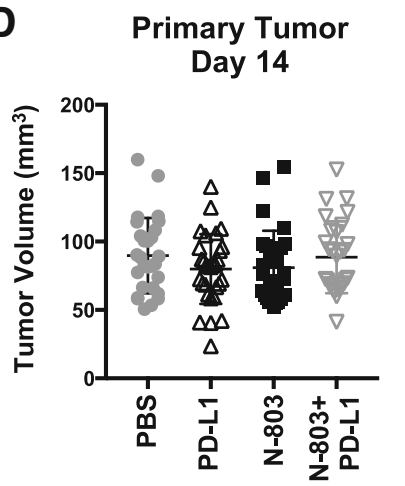

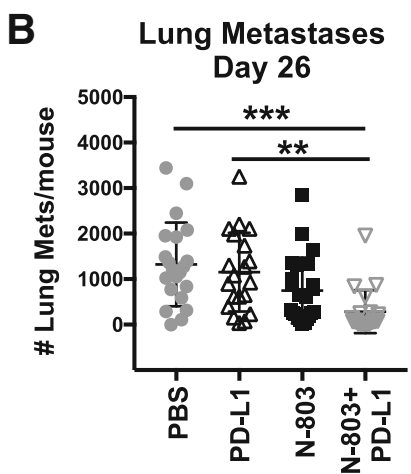

E

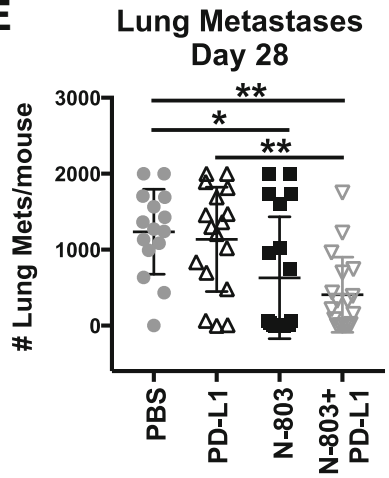

C

\begin{tabular}{|c|c|c|c|c|}
\hline \multicolumn{5}{|c|}{ Lung Metastases } \\
\hline $\begin{array}{l}\text { \# Lung } \\
\text { Mets/ } \\
\text { mouse }\end{array}$ & $\begin{array}{c}\text { PBS } \\
(n=21)\end{array}$ & $\begin{array}{l}\text { PD-L1 } \\
(n=20)\end{array}$ & $\begin{array}{l}N-803 \\
(n=23)\end{array}$ & $\begin{array}{c}\text { N-803+ } \\
\text { PD-L1 } \\
(n=20)\end{array}$ \\
\hline$\geq 2000$ & $4 / 21(19 \%)$ & $4 / 20(20 \%)$ & $1 / 23(4 \%)$ & $0 / 20(0 \%)$ \\
\hline$\leq 2000$ & \begin{tabular}{|l|}
$17 / 21(81 \%)$ \\
\end{tabular} & $16 / 20(80 \%)$ & $22 / 23(96 \%)$ & $20 / 20(100 \%)$ \\
\hline$\leq 1000$ & $7 / 21(33 \%)$ & $10 / 20(50 \%)$ & $17 / 23(74 \%)$ & $19 / 20(85 \%)$ \\
\hline$\leq 500$ & $4 / 21(19 \%)$ & $5 / 20(25 \%)$ & $11 / 23(48 \%)$ & $16 / 20(80 \%)$ \\
\hline$\leq 100$ & $1 / 21(5 \%)$ & $2 / 20(10 \%)$ & $2 / 23(9 \%)$ & $11 / 20(55 \%)$ \\
\hline 0 & $1 / 21(5 \%)$ & $0 / 20(0 \%)$ & $0 / 23(0 \%)$ & $1 / 20(5 \%)$ \\
\hline Mean & 1324 & 1153 & 749 & 286 \\
\hline$\%$ Reduction & $0 \%$ & $13 \%$ & $43 \%$ & $78 \%$ \\
\hline
\end{tabular}

F

Lung Metastases

\begin{tabular}{|c|c|c|c|c|}
\hline $\begin{array}{c}\text { \# Lung } \\
\text { Mets/ } \\
\text { mouse }\end{array}$ & $\begin{array}{c}\text { PBS } \\
(n=15)\end{array}$ & $\begin{array}{l}\text { PD-L1 } \\
(n=17)\end{array}$ & $\begin{array}{l}N-803 \\
(n=19)\end{array}$ & $\begin{array}{c}\text { N-803+ } \\
\text { PD-L1 } \\
(n=18)\end{array}$ \\
\hline$\geq 1000$ & $11 / 15(73 \%)$ & $11 / 17(65 \%)$ & $6 / 19(31 \%)$ & $2 / 18(11 \%)$ \\
\hline$\leq 1000$ & $4 / 15(26 \%)$ & $6 / 17(35 \%)$ & $13 / 19(68 \%)$ & $16 / 18(88 \%)$ \\
\hline$\leq 500$ & $2 / 15(13 \%)$ & $4 / 17(24 \%)$ & $11 / 19(57 \%)$ & $13 / 18(72 \%)$ \\
\hline$\leq 100$ & $1 / 15(6 \%)$ & $3 / 17(18 \%)$ & $11 / 19(57 \%)$ & $7 / 18(38 \%)$ \\
\hline$\leq 50$ & $1 / 15(6 \%)$ & $2 / 17(12 \%)$ & $9 / 19(47 \%)$ & $6 / 18(33 \%)$ \\
\hline 0 & $0 / 15(0 \%)$ & $1 / 17(5 \%)$ & $5 / 19(26 \%)$ & $2 / 18(11 \%)$ \\
\hline Mean & 1236 & 1136 & 630 & 407 \\
\hline Reduction & $0 \%$ & $8 \%$ & $49 \%$ & $67 \%$ \\
\hline
\end{tabular}

G Survival

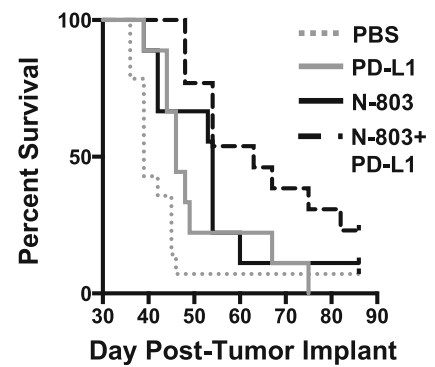

\begin{tabular}{|lcccc|} 
& PBS & PD-L1 & N-803 & $\begin{array}{c}\text { N-803+ } \\
\text { PD-L1 }\end{array}$ \\
\hline $\begin{array}{l}\text { Median OS (d) } \\
\begin{array}{l}\text { Mantel-Cox } \\
\text { vs. PBS }\end{array}\end{array}$ & 39 & 46 & 54 & 63 \\
$\begin{array}{l}\text { vs. N-803+ } \\
\text { PD-L1 }\end{array}$ & p $<0.001$ & $p=0.009$ & $p=0.038$ & $p<0.001$ \\
\hline
\end{tabular}

Fig. 2 Combination of N-803 and aPD-L1 decreases 4T1 lung metastasis and improves survival. a-c Mice were implanted with 4T1 tumors as in Fig. 1 and treated on days 8 and 14 with $1 \mu \mathrm{g} \mathrm{N-803} \mathrm{(s.c.)} \mathrm{and/or} 200 \mu \mathrm{g}$ aPD-L1 (i.p.) on days 8, 11, and 14. Graphs of tumor volumes of individual animals at day 25 post-tumor implant in (a) and number of lung metastases in individual mice 26 days after tumor implant (b) show mean \pm SD. $\mathbf{c}$ Table denotes the distribution of number of lung metastases and \% reduction in mean versus PBS. Data are representative of 2 independent experiments, $n=20-23$ mice. $\mathbf{d}-\mathbf{g}$ Mice were implanted with 4T1 tumors as in Fig. 1 and treated at days 9 and 13 with N-803 and/or aPD-L1 on days 9,11 , and 13. The primary tumor was surgically resected at day 15. Graphs of tumor volumes of individual animals at day 14 post-tumor implant (d) and number of lung metastases in individual mice at day 28 (e) show mean \pm SD. $\mathbf{f}$ Table denotes the distribution of number of lung metastases per mouse and \% reduction in mean versus PBS. Data are representative of 2 independent experiments, $n=15-19$ mice. g Survival curves (inset: mOS) show $\%$ survival. Data are representative of 2 independent experiments, $n=13-19$ mice

anti-tumor efficacy of N-803 $+\alpha$ PD-L1 (Additional file 1: Figure S4D-G). These results indicate NK cells, and to a lesser extent $\mathrm{CD} 8^{+} \mathrm{T}$ cells, are required for the anti-tumor efficacy of N-803 $+\alpha \mathrm{PD}-\mathrm{L} 1$ therapy in 4T1 tumor-bearing mice.

In order to confirm the requirement of $\mathrm{CD}^{+} \mathrm{T}$ cells and NK cells for responsiveness to N-803+ + PD-L1 therapy, we also performed $\mathrm{CD}^{+} \mathrm{T}$ cell and NK cell depletions in MC38-CEA tumor-bearing mice. N-803 $+\alpha$ PD-L1 reduced primary tumor burden (Additional file 1: Figure $S 5 A, B)$ and increased mOS by $33 \%$ versus PBS treatment (Additional file 1: Figure S5C). Depletion of $\mathrm{CD}^{+} \mathrm{T}$ cells, NK cells, and both $\mathrm{CD}^{+} \mathrm{T}$ cells and 


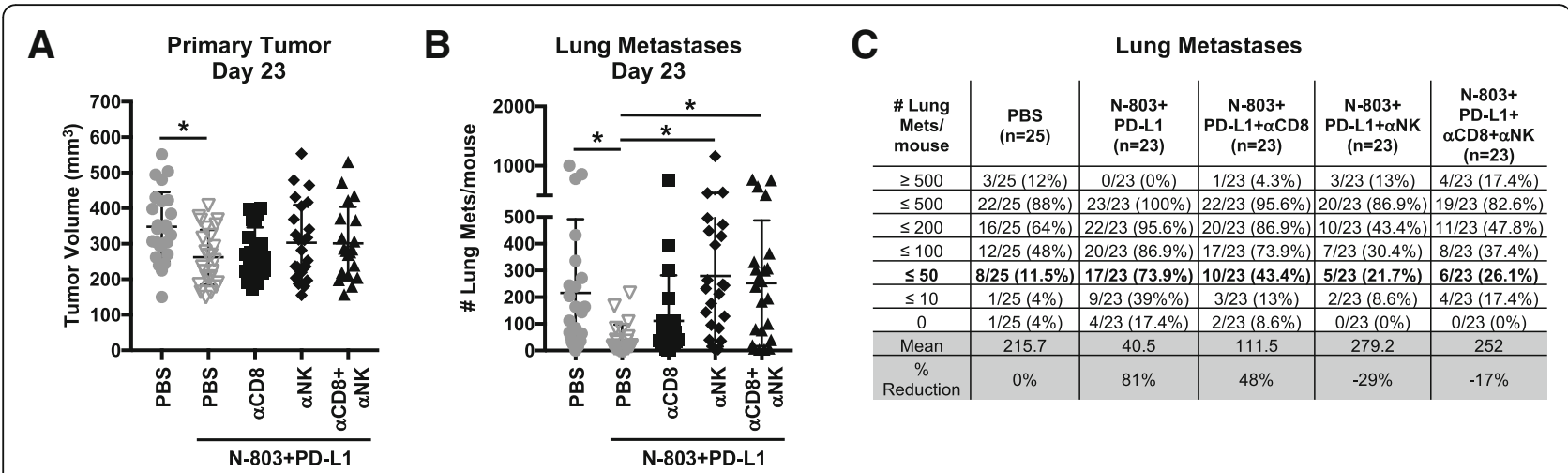

Fig. $3 \mathrm{CD}^{+} \mathrm{T}$ cells and NK cells contribute to the anti-tumor efficacy of N-803 + aPD-L1 combination. Mice were implanted with 4T1 tumors as in Fig. 1 and treated on days 13 and 17 with N-803 and aPD-L1 on days 13, 15, and 17. CD8-expressing cells and NK cells were depleted on days 10, 11, 12, 16, and 19 using $100 \mu \mathrm{g}$ anti-CD8 and/or $25 \mu$ anti-asialo-GM1 (i.p.). Graphs show tumor volumes of individual mice (a) or number of lung metastases in individual mice at day 23 post-tumor implant (b) as mean \pm SD. c Table denotes the distribution of the number of lung metastases per mouse and \% reduction in mean versus PBS. Data combined from 2 independent experiments, $n=23-25$ mice/group total
NK cells completely abrogated the anti-tumor efficacy of $\mathrm{N}-803+\alpha \mathrm{PD}-\mathrm{L} 1$ (Additional file 1: Figure S5A,B). All of the depletion strategies similarly reduced $\mathrm{mOS}$ by 45 and $9 \%$ versus $\mathrm{N}-803+\alpha \mathrm{PD}-\mathrm{L} 1$ and PBS treatment, respectively (Additional file 1: Figure $\mathrm{S} 5 \mathrm{C}$ ). Thus, $\mathrm{CD}^{+} \mathrm{T}$ cells and NK cells are equally required for the efficacy of $\mathrm{N}-803+\alpha$ PD-L1 in MC38-CEA tumor-bearing mice.

\section{$\mathrm{N}-803+$ aPD-L1 treatment decreases $\mathrm{T}_{\text {reg }}$ and G-MDSC numbers in the lung}

To further elucidate the mechanism of $\mathrm{N}-803+\alpha \mathrm{PD}-\mathrm{L} 1-$ induced anti-tumor efficacy, we performed a comprehensive characterization of immune cell populations in the primary tumor, in the lung as a site of metastasis, and in the peripheral immune compartment in the spleen of $4 \mathrm{~T} 1$ tumor-bearing mice $24 \mathrm{~h}$ after the last $\mathrm{N}-803$ and/or $\alpha \mathrm{PD}-\mathrm{L} 1$ treatment. The effect of N-803 $+\alpha \mathrm{PD}-\mathrm{L} 1$ combination on the immune system in murine solid carcinoma models has not been previously reported.

While we were particularly interested in $\mathrm{NK}$ and $\mathrm{CD} 8^{+}$ $T$ cells, given the results of the depletion studies, we first investigated the effect of $\mathrm{N}-803+\alpha \mathrm{PD}-\mathrm{L} 1$ therapy on regulatory $\mathrm{T}$ cell $\left(\mathrm{T}_{\text {reg }}\right)$ and MDSC populations, as these immunosuppressive cells play important roles in the progression of $4 \mathrm{~T} 1$ tumors $[31,32]$. $\mathrm{T}_{\text {reg }}$ numbers were significantly decreased in the lung vasculature, but not in other immune compartments, with all treatments (Additional file 1: Figure S6). In addition, N-803 $+\alpha \mathrm{PD}-\mathrm{L} 1$ treatment decreased the number of G-MDSC/ granulocytes in the lung parenchyma and vasculature (Additional file 1: Figure S7A). $\alpha$ PD-L1 and N-803 also reduced G-MDSC/granulocytes in the lung parenchyma or vasculature, respectively (Additional file 1: Figure S7A). There was no effect on the number or frequency of the M-MDSC/monocyte population (Additional file 1: Figure S7B). Thus, N-803 $+\alpha$ PD-L1 combination decreases immunosuppressive $\mathrm{T}_{\text {reg }}$ and G-MDSC/granulocyte populations in the lung.

\section{$\mathrm{N}-803$ and $\mathrm{N}-803+$ aPD-L1 treatments promote the development of an activated NK cell phenotype in the lung and spleen and increase NK cell function}

Given the necessity of NK cells for $\mathrm{N}-803+\alpha \mathrm{PD}-\mathrm{L} 1$ anti-tumor efficacy, we examined the effect of combination therapy on NK cell phenotype. Furthermore, while N-803 is known to greatly increase the number and activation of NK cells in the tumor and spleen of tumor-bearing mice [9-11], the effect of subcutaneous $\mathrm{N}-803$ plus checkpoint blockade on NK cell phenotype and function has not been reported. In the primary tumor, N-803 $+\alpha$ PD-L1 did not affect NK cell number (Fig. 4a), frequency (Additional file 1: Figure S8A), or expression of activation-associated receptors NKG2D (Fig. 4b) or NKp46 (Additional file 1: Figure $\mathrm{S} 8 \mathrm{~B})$. There was, however, a significant increase in the proportion of $\mathrm{Ki}^{+} 7^{+} \mathrm{NK}$ cells (Fig. 4c), indicating an increased proliferative potential.

Given the significant reduction in lung tumor burden with $\mathrm{N}-803+\alpha \mathrm{PD}-\mathrm{L} 1$ (Fig. 2), NK cell populations in the lung were of particular interest. We could not detect NK cells in the lung parenchyma due to low cell number, but we did examine NK cells in the lung vasculature. N-803 $+\alpha$ PD-L1 greatly increased the number (Fig. 4a) and frequency (Additional file 1: Figure S8A) of vascular NK cells in the lung versus PBS and $\alpha$ PD-L1. The proportion of NK cells expressing NKG2D (Fig. 4b) and Ki67 (Fig. 4c) and expression of NKp46 (Additional file 1: Figure S8B) were also significantly enhanced with $\mathrm{N}-803+\alpha \mathrm{PD}-\mathrm{L} 1$ versus PBS treatment. N-803 $+\alpha$ PD-L1-induced changes to splenic NK cell populations were similar to those observed in the lung vasculature (Fig. 4a-c and Additional file 1: Figure S8A,B). The increased cell numbers and expression of activation-associated proteins with $\mathrm{N}-803+\alpha \mathrm{PD}-\mathrm{L} 1$ 


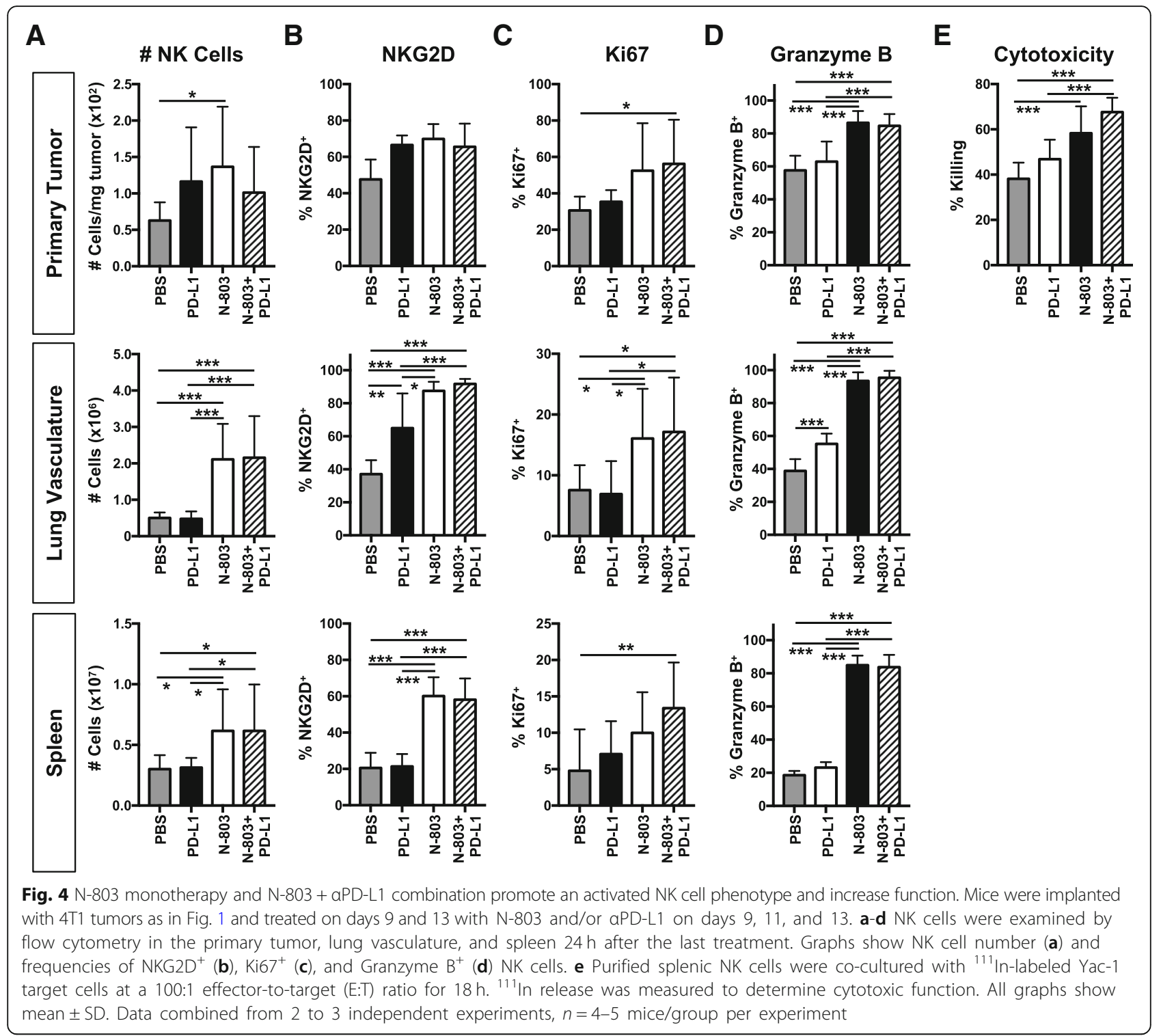

treatment appeared to be driven by $\mathrm{N}-803$, as similar increases were observed with $\mathrm{N}-803$, but not $\alpha \mathrm{PD}-\mathrm{L} 1$, monotherapy (Fig. 4a-c and Additional file 1: Figure S8A,B).

The changes to NK cell phenotype with N-803 $+\alpha$ PD-L1 combination suggested that NK cell function would be markedly enhanced. As expected, N-803 $+\alpha$ PD-L1 treatment significantly increased the population of NK cells expressing the cytolytic molecule Granzyme $B$ in the primary tumor, lung vasculature, and spleen versus PBS and $\alpha$ PD-L1 treatments (Fig. $4 \mathrm{~d}$ and Additional file 1: Figure S8C). Increased Granzyme B expression correlated with a profound enhancement of NK cell killing of Yac- 1 target cells with $\mathrm{N}-803+\alpha \mathrm{PD}-\mathrm{L} 1$ versus PBS and $\alpha \mathrm{PD}-\mathrm{L} 1$ treatments (Fig. 4e). In addition, a greater proportion of splenic and lung vascular NK cells produced IFN $\gamma$, and the amount of IFN $\gamma$ produced on a per cell basis increased with $\mathrm{N}-803+\alpha \mathrm{PD}-\mathrm{L} 1$ therapy (Additional file 1: Figure S8D). Again, similar results were seen with $\mathrm{N}-803$ and $\mathrm{N}-803+\alpha \mathrm{PDL} 1$ treatments (Fig. 4d,e and Additional file 1: Figure S8C,D). Together, these results suggest that N-803 $+\alpha$ PD-L1 therapy supports anti-tumor efficacy through enhanced NK cell activation and function primarily in the lung and spleen, and this effect is mainly driven by $\mathrm{N}-803$.

$\mathrm{N}-803+$ aPD-L1 therapy induces an activated $\mathrm{CD}^{+} \mathrm{T}$ cell phenotype in the lung and spleen and enhances effector function

The increased anti-tumor efficacy of $\mathrm{N}-803+\alpha \mathrm{PD}-\mathrm{L} 1$ versus N-803 monotherapy could not be fully explained by differences in NK cell phenotype and function, as both treatments induced similar changes to these cells. 
While $\mathrm{CD}^{+} \mathrm{T}$ cells contributed less to the reduction of $4 \mathrm{~T} 1$ lung metastasis by $\mathrm{N}-803+\alpha \mathrm{PD}-\mathrm{L} 1$ than NK cells, they did partially support this anti-tumor efficacy (Fig. 3). It is known that both $\mathrm{N}-803$ and $\alpha \mathrm{PD}-\mathrm{L} 1$ monotherapies enhance $\mathrm{CD} 8^{+} \mathrm{T}$ cell proliferation, activation, and function [9-12], but the effect of combining N-803 plus checkpoint blockade on $\mathrm{CD}^{+} \mathrm{T}$ cells has not been elucidated. Similar to NK cells, there were no significant differences in $\mathrm{CD}^{+} \mathrm{T}$ cell number (Fig. 5a) or phenotype (Fig. 5b-d) in the primary tumor with treatment, other than an increase in the frequency of $\mathrm{Ki} 67^{+} \mathrm{CD}^{+} \mathrm{T}$ cells (Fig. 5d), indicating an increased proliferative potential. In the lung, N-803 $+\alpha$ PD-L1 therapy enhanced lung parenchymal-resident $\mathrm{CD}^{+} \mathrm{T}$ cell number (Fig. 5a) and the proportion of activated CD44 ${ }^{\text {hi }}$ (Fig. 5b) and Ki67-expressing (Fig. 5d) cells. In the lung vasculature, there was also a significant enrichment of the population of activated $\mathrm{CD} 44^{\text {hi }} \mathrm{CD} 8^{+} \mathrm{T}$ cells (Fig. $5 \mathrm{~b})$, specifically of a central memory $\left(\mathrm{T}_{\mathrm{CM}}\right)$ phenotype (Fig. 5 c), after N-803 $+\alpha$ PD-L1 versus PBS treatment. $\mathrm{N}-803+\alpha \mathrm{PD}-\mathrm{L} 1$ therapy also greatly altered the splenic $\mathrm{CD}^{+} \mathrm{T}$ cell population. While N-803 $+\alpha \mathrm{PD}-\mathrm{L} 1$ did not affect $\mathrm{CD}^{+} \mathrm{T}$ cell number (Fig. 5a) versus PBS treatment, combination therapy augmented the frequency of Ki67 ${ }^{+}$ (Fig. 5d) and activated CD44 ${ }^{\text {hi }} \mathrm{CD} 8^{+} \mathrm{T}$ cells (Fig. 5b), in particular those with a $\mathrm{T}_{\mathrm{CM}}$ phenotype (Fig. 5c). Similar to NK cells, the changes in $\mathrm{CD}^{+} \mathrm{T}$ cell number and phenotype, with the exception of Ki67, appeared dependent on N-803, but not $\alpha$ PD-L1, monotherapy (Fig. 5).

Sustained, elevated levels of PD- 1 on T cells can correlate with the development of $\mathrm{CD}^{+} \mathrm{T}$ cell exhaustion [12]. Both IL-15 treatment and PD-L1 blockade have been shown to reduce $\mathrm{T}$ cell exhaustion $[1,12]$, but the effect of $\mathrm{N}-803+\alpha \mathrm{PD}-\mathrm{L} 1$ therapy on this process has not been described. We examined the expression of PD-1 on CD8 ${ }^{+} \mathrm{T}$ cells after treatment. One day after the final treatment, at day 14, PD-1 expression was low on $\mathrm{CD}^{+} \mathrm{T}$ cells (Additional file 1: Figure S9). By day 21 post-tumor implant, $\mathrm{CD} 8^{+} \mathrm{T}$ cells expressed significantly less PD-1 after $\mathrm{N}-803+\alpha \mathrm{PD}-\mathrm{L} 1$ than PBS treatment (Additional file 1: Figure S9), suggesting they may be less exhausted. Importantly, this reduction was only seen with $\mathrm{N}-803+\alpha \mathrm{PD}-\mathrm{L} 1$ and not $\alpha \mathrm{PD}-\mathrm{L} 1$ or N-803 monotherapy (Additional file 1: Figure S9).

The development of a more active $\mathrm{CD} 8^{+} \mathrm{T}$ cell phenotype with $\mathrm{N}-803+\alpha \mathrm{PD}-\mathrm{L} 1$ treatment suggested that $\mathrm{CD}^{+} \mathrm{T}$ cell effector function would also be improved. After $\mathrm{N}-803+\alpha \mathrm{PD}-\mathrm{L} 1$ treatment, $\mathrm{CD} 8^{+} \mathrm{T}$ cells in the lung and spleen expressed more Granzyme $\mathrm{B}$ than all other treatment groups, including $\mathrm{N}-803$ monotherapy (Fig. 6a and Additional file 1: Figure S10A). $\mathrm{CD}^{+} \mathrm{T}$ cells also expressed more Granzyme B in the primary tumor with $\mathrm{N}-803+\alpha \mathrm{PD}-\mathrm{L} 1$ treatment versus PBS and N-803 treatments (Fig. 6a and Additional file 1: Figure S10A).
In addition, combination therapy significantly increased the proportion of all IFN $\gamma$-producing $\mathrm{CD}^{+}{ }^{+} \mathrm{T}$ cells versus PBS treatment in the lung parenchyma and versus all other treatments in the lung vasculature and spleen (Fig. 6b). IFN $\gamma$ production on a per cell basis was not altered with treatment (Additional file 1: Figure S10B). While the proportion of all TNF $\alpha$-producing $\mathrm{CD}^{+} \mathrm{T}$ cells did not increase with $\mathrm{N}-803+\alpha \mathrm{PD}-\mathrm{L} 1$ treatment except in the spleen, there was a minor increase in TNF $\alpha$ production on a per cell basis as compared to PBS treatment in the lung (Additional file 1: Figure S10C). Together, the increased frequency of IFN $\gamma$-producing cells with $\mathrm{N}-803+\alpha \mathrm{PD}-\mathrm{L} 1$ therapy translated into a greater proportion of $\mathrm{CD}^{+} \mathrm{T}$ cells that were IFNy single producers (IFN $\gamma^{+} \mathrm{TNF}^{-}$) (Fig. 6c) and IFN $\gamma / \mathrm{TNF} \alpha$ $\left(\mathrm{IFN} \gamma^{+} \mathrm{TNF}^{+}\right.$) double producers (Fig. $6 \mathrm{~d}$ ).

Together, these results suggest that $\mathrm{N}-803+\alpha \mathrm{PD}-\mathrm{L} 1$ therapy improves $\mathrm{CD} 8^{+} \mathrm{T}$ cell activation and expansion in the peripheral immune compartments, and that this effect on $\mathrm{CD}^{+} \mathrm{T}$ cell phenotype is mainly driven by $\mathrm{N}-803$. However, maximal enhancement of $\mathrm{CD}^{+} \mathrm{T}$ cell function requires $\mathrm{N}-803$ and $\alpha \mathrm{PD}-\mathrm{L} 1$ in combination, as $\mathrm{N}-803+\alpha \mathrm{PD}-\mathrm{L} 1$ treatment increases effector molecule and cytokine production over both $\mathrm{N}-803$ and $\alpha \mathrm{PD}-\mathrm{L} 1$ monotherapies at the tumor sites and in the periphery.

\section{$\mathrm{N}-803+$ aPD-L1 treatment induces high levels of serum immunostimulatory cytokines IFN $Y$ and TNFa in the absence of toxicity}

Together, the aforementioned results suggest that $\mathrm{N}-803+\alpha \mathrm{PD}-\mathrm{L} 1$ therapy would induce significantly higher global levels of immunostimulatory cytokines IFN $\gamma$ and $\mathrm{TNF} \alpha$, driven by $\mathrm{CD} 8^{+} \mathrm{T}$ and $\mathrm{NK}$ cell production, as compared to $\alpha \mathrm{PD}-\mathrm{L} 1$ and $\mathrm{N}-803$ monotherapies. Along with the proinflammatory cytokine IL-6, sustained high levels of IFN $\gamma$ and TNF $\alpha$ can induce significant clinical toxicities, as was seen in early rIL-15 clinical trials [6-8]. Thus, we examined the kinetics of global serum cytokine levels. Twenty-four hours after the last treatment, N-803 $+\alpha$ PD-L1 therapy induced significantly higher levels of serum IFNY (Fig. 7a) and TNF $\alpha$ (Fig. 7b) than all other treatments. The anti-inflammatory cytokine IL-10 (Fig. 7c) was also markedly enhanced versus PBS and N-803 therapy. The increased IFN $\gamma$, TNF $\alpha$, and IL-10 levels were transient, as they returned to PBStreated concentrations by day 21 or 7 days after treatment (Fig. 7a-c). IL-6 was not significantly increased in the serum with N-803 $+\alpha$ PD-L1 treatment (Fig. $7 d$ ). Importantly, even with the highly elevated levels of IFNy with $\mathrm{N}-803+\alpha \mathrm{PD}-\mathrm{L} 1$ treatment, the combination was well-tolerated. At $1 \mu \mathrm{g} \mathrm{N}-803$ plus $200 \mu \mathrm{g} \alpha \mathrm{PD}-\mathrm{L} 1$, there was no significant loss of body weight observed when compared to PBS treatment (Additional file 1: Figure S2D-E). In all, these results support that 


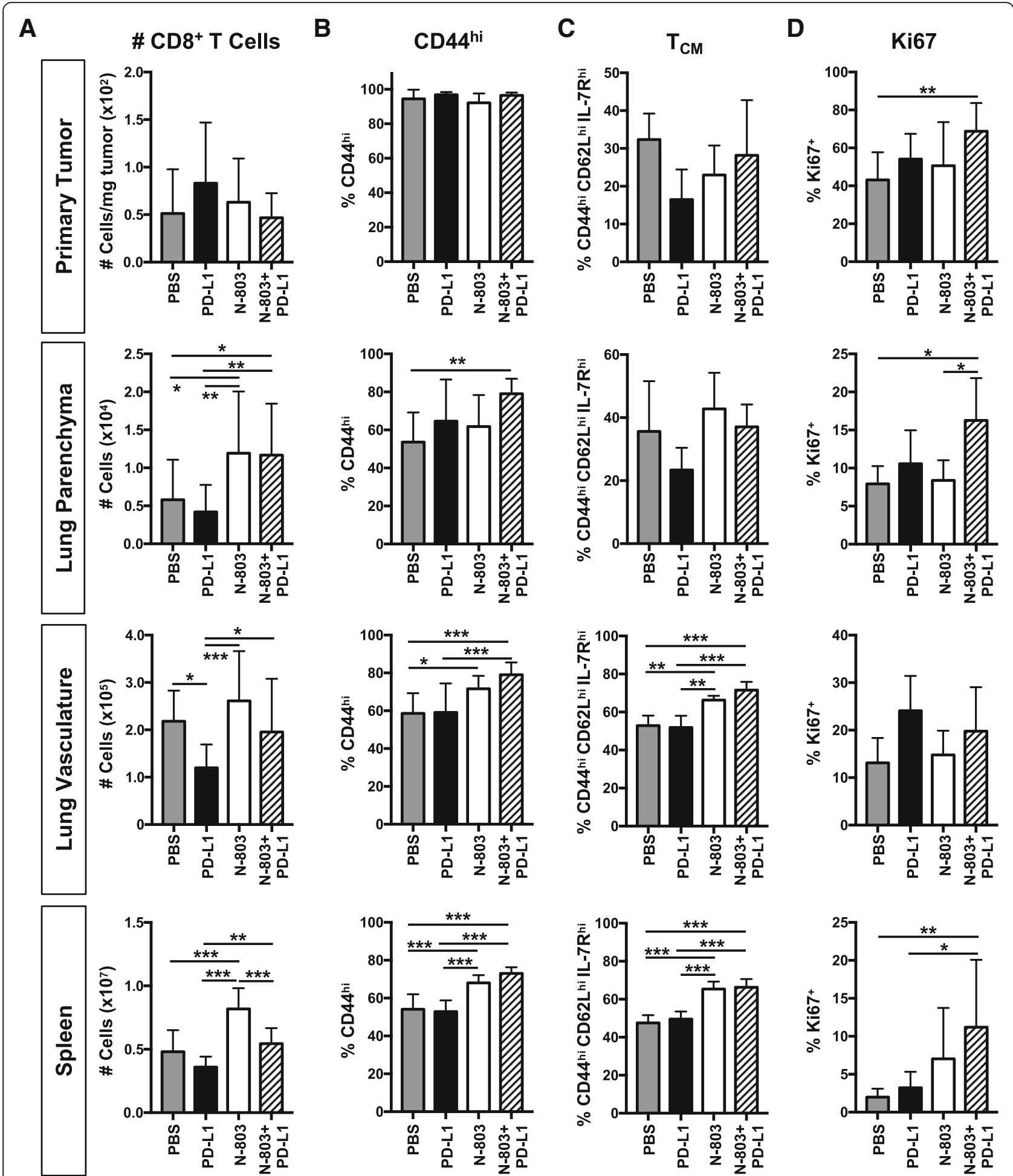

Fig. 5 Combination of N-803 + aPD-L1 induces an activated CD8 ${ }^{+}$T cell phenotype. Mice were implanted with $4 \mathrm{~T} 1$ tumors as in Fig. 1 and treated on days 9 and 13 with N-803 and/or aPD-L1 on days 9, 11, and 13. CD8 $8^{+}$T cells were examined by flow cytometry in the primary tumor, lung parenchyma and vasculature, and spleen $24 \mathrm{~h}$ after the last treatment. Graphs of CD $8^{+} \mathrm{T}$ cell number $(\mathbf{a})$, frequency of CD44 ${ }^{\text {hi }}(\mathbf{b}), \mathrm{CD} 44^{\mathrm{hi}} \mathrm{CD} 62 \mathrm{~L}^{\mathrm{hi}}$ $\mathrm{T}_{\mathrm{CM}}(\mathbf{c})$, and Ki67 $7^{+} \mathrm{CD} 44^{\text {hi }}$ (d) $\mathrm{CD} 8^{+} \mathrm{T}$ cells show mean $\pm \mathrm{SD}$. Data combined from 2 to 3 independent experiments, $n=5$ mice/group per experiment 


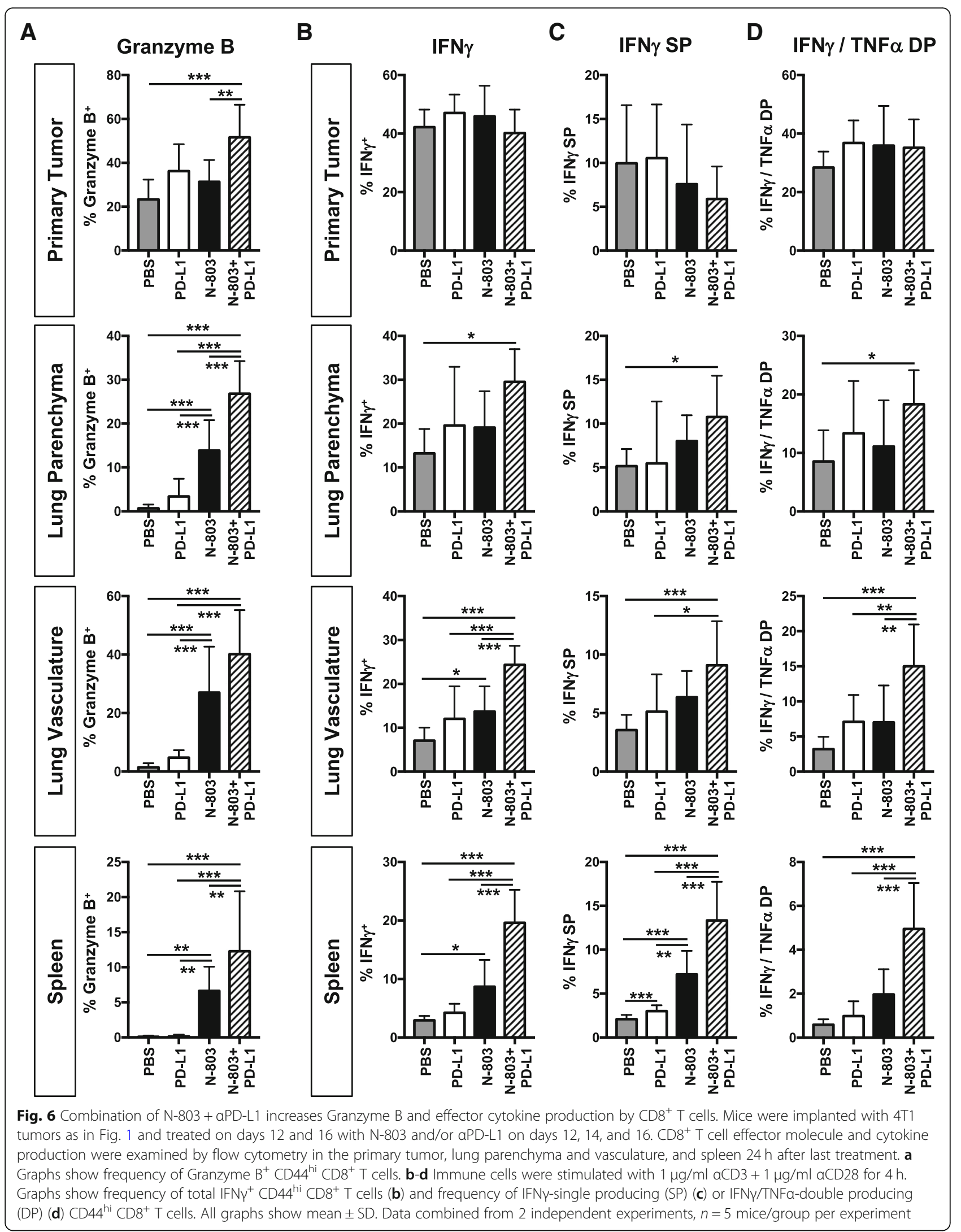




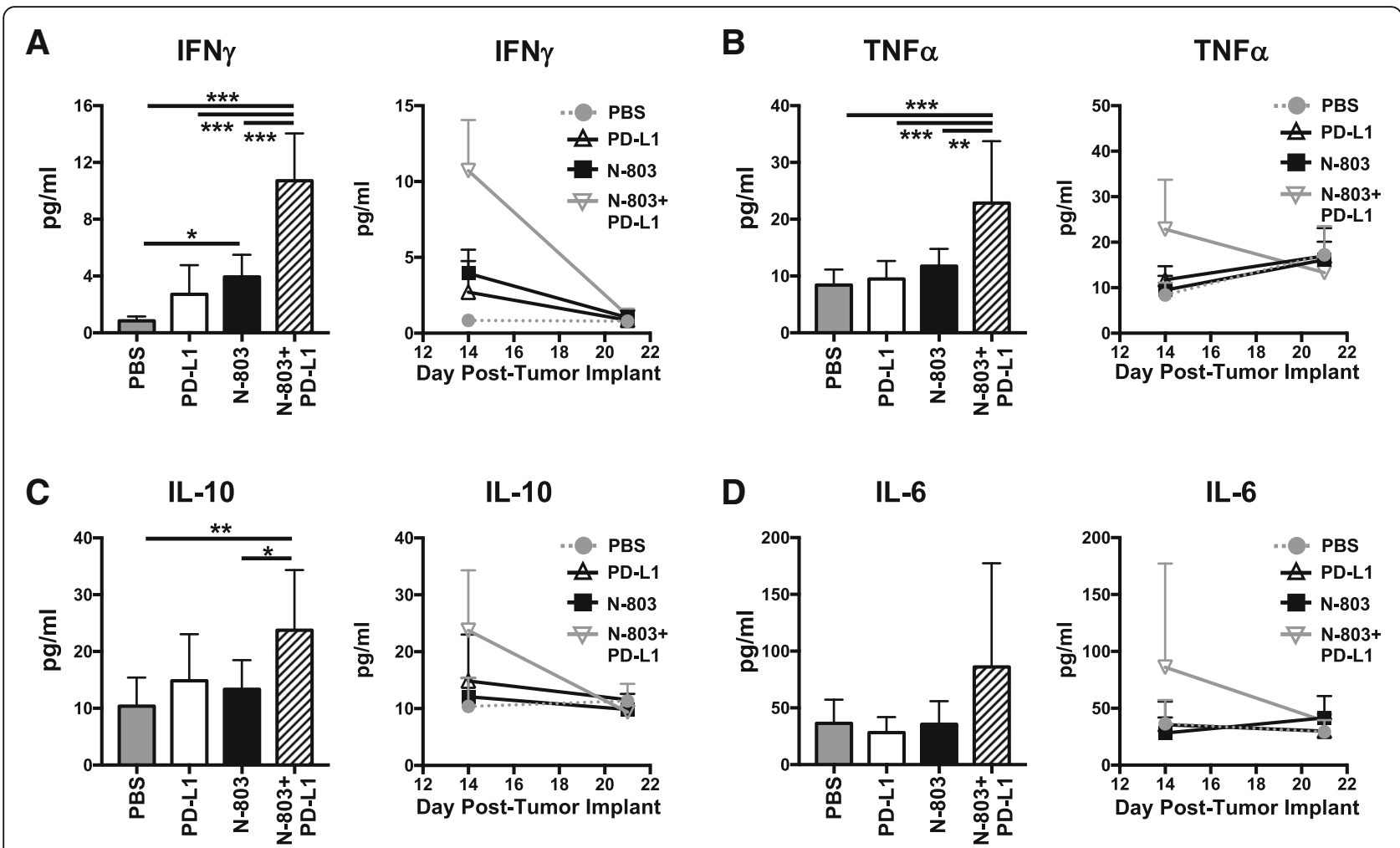

Fig. $7 \mathrm{~N}-803$ + aPD-L1 combination promotes the generation of an immunostimulatory milieu in the serum. Mice were implanted with 4T1 tumors as in Fig. 1 and treated on days 9 and 13 with N-803 and/or APD-L1 on days 9, 11, and 13. Serum was obtained at days 14 and 21 post-tumor implant and analyzed for level of IFNY (a), TNFa (b), IL-10 (c), and IL-6 (d). Level of serum cytokines from individual animals at day 14 (left panels) and curves showing kinetics of serum cytokine levels (right panels) show mean \pm SD. Data are combined from 2 experiments, $n=4-5$ mice/group per experiment

$\mathrm{N}-803+\alpha \mathrm{PD}-\mathrm{L} 1$ combination is uniquely able to induce a transient, immunostimulatory environment that promotes significant anti-tumor efficacy without inducing significant toxicity.

\section{Discussion}

Cytokine therapy and immune checkpoint blockade are two major immunotherapy modalities in oncology. In the studies presented here, we combined the IL-15/ IL-15R $\alpha$ Sushi-Fc superagonist N-803 with a PD-L1-targeted antibody. To our knowledge, these studies are the first to evaluate the anti-tumor efficacy of N-803 administered subcutaneously, the route used in the clinic $[7,8$, $23]$, as a monotherapy or in combination with checkpoint inhibition in murine models of solid carcinomas. $\mathrm{N}-803+\alpha$ PD-L1 treatment was well-tolerated, elicited significant anti-tumor efficacy, and improved survival in the 4T1 TN breast and MC38-CEA colon carcinoma models. This is in contrast to monotherapy-treated mice, where each model responded to different components of the combination therapy in isolation. While 4T1 lung metastasis was refractory to $\alpha \mathrm{PD}-\mathrm{L} 1$ therapy, it was partially responsive to N-803. MC38-CEA tumors responded in the opposite fashion. These results uniquely demonstrate that N-803 $+\alpha \mathrm{PD}-\mathrm{L} 1$ combination elicits broader anti-tumor efficacy as compared to either monotherapy. This could be beneficial in the clinic where tumor type can determine resistance to immunotherapy and many patients with solid carcinomas have an innate or acquired resistance to checkpoint blockade $[33,34]$. As reported here using the $4 \mathrm{~T} 1$ model, the addition of $\mathrm{N}-803$ to $\alpha \mathrm{PD}-\mathrm{L} 1$ therapy may convert $\alpha$ PD-L1 poor or non-responding patients into responders. This is supported by a recent clinical study (NCT02523469) in which 91\% of PD-1 treatment-resistant metastatic NSCLC patients achieved disease control, with $27 \%$ partial responses and $64 \%$ stable disease after concurrent treatment with $\mathrm{N}-803$ and the $\alpha \mathrm{PD}-1$ antibody nivolumab [23]. It is possible that similar results will be seen in patients treated with the combination of $\mathrm{N}-803$ and $\alpha \mathrm{PD}-\mathrm{L} 1$. Unfortunately, direct examination of $\mathrm{N}-803$-mediated reversion of acquired $\alpha \mathrm{PD}-\mathrm{L} 1$ resistance is not feasible using these aggressive murine tumor models. The duration of these experiments is ethically limited due to tumor growth to approximately 4 weeks, preventing long-term experiments where mice could be dosed sequentially with $\alpha$ PD-L1 followed by $\mathrm{N}-803$. In addition, repeated dosing with the $\alpha$ PD-L1 antibody 
(rat) or N-803 (human) can generate anti-rat and anti-human immune responses, respectively, reducing the efficacy of these treatments over time with potential severe toxicity. It has been reported that repeated dosing of 4T1 tumor-bearing mice with $\alpha \mathrm{PD}-\mathrm{L} 1$ antibodies induces fatal hypersensitivity [35].

While the mechanism of action of $\mathrm{N}-803$ monotherapy has been investigated in multiple preclinical murine models and in patients $[4,5,7,9,10]$, the studies presented here are the first to report the immune mechanism by which $\mathrm{N}-803+\alpha$ PD-L1 combination mediates anti-tumor efficacy. Furthermore, these studies are the first to comprehensively interrogate and compare the immune response in multiple immune compartments, including the primary tumor, a site of metastasis, and in the periphery. Similar to other N-803 monotherapy studies $[4,9]$, efficacy of N-803 $+\alpha$ PD-L1 was dependent on $\mathrm{NK}$ and $\mathrm{CD}^{+} \mathrm{T}$ cells, but the relative contributions of these two immune cell populations was dependent on the tumor model and tumor site analyzed. In the 4T1 TN breast carcinoma model, depletion of NK cells abrogated the reduction in lung tumor burden by $\mathrm{N}-803$ $+\alpha$ PD-L1, while loss of $\mathrm{CD}^{+}{ }^{+} \mathrm{T}$ cells increased the mean number of lung metastases by $175 \%$. This suggests that for control of lung metastases, NK cells can compensate for the loss of $\mathrm{CD}^{+} \mathrm{T}$ cells, but $\mathrm{CD} 8^{+} \mathrm{T}$ cells cannot compensate for the loss of NK cells. NK cells have previously been shown to be important for immunosurveillance of the lung [36], a unique immunological environment highly dependent on innate immune surveillance due to its constant expose to exogenous particles, and to contribute to the detection and elimination of tumor cells during the initial immune response in the lung $[37,38]$. By contrast, both $\mathrm{CD}^{+} \mathrm{T}$ cells and NK cells highly contributed to the anti-tumor efficacy of $\mathrm{N}-803+\alpha \mathrm{PD}-\mathrm{L} 1$ in MC38-CEA colon carcinoma model, with loss of either immune population increasing primary tumor growth. Thus, a therapy such as $\mathrm{N}-803$ $+\alpha \mathrm{PD}-\mathrm{L} 1$, which targets both $\mathrm{CD} 8^{+} \mathrm{T}$ and NK cells, may support broader tumor control than a therapy that affects only one of these immune cell populations.

Here, we demonstrated that both $\mathrm{CD} 8^{+} \mathrm{T}$ cells and NK cells were expanded in peripheral immune sites and displayed enhanced expression of activation-associated proteins with $\mathrm{N}-803+\alpha \mathrm{PD}-\mathrm{L} 1$. These results are similar to those observed in the Phase I clinical trial with the combination of nivolumab plus $\mathrm{N}$-803. In the peripheral blood of treated patients, NK cells more than doubled within 7 days post-treatment [23]. While $\mathrm{CD}^{+} \mathrm{T}$ cells did not expand to the same extent, both $\mathrm{CD}^{+}{ }^{+} \mathrm{T}$ cells and NK cells expressed 2- and 3-fold higher levels of Ki67 after 4 days, respectively [23]. Likewise, we observed a greater expansion of $\mathrm{NK}$ cells than $\mathrm{CD} 8^{+} \mathrm{T}$ cells in the lung vasculature and spleen 2 days after the final treatment with $\mathrm{N}-803$ and $\mathrm{N}-803+\alpha \mathrm{PD}-\mathrm{L} 1$, as well as significant upregulation of Ki67 in both immune populations in the spleen. While the effects on both $\mathrm{CD} 8^{+} \mathrm{T}$ cell and NK cell phenotype were highly dependent on the N-803 component, with minimal differences observed between the immune compartments in N-803- and N-803 $+\alpha$ PD-L1-treated mice, $\mathrm{CD}^{+} \mathrm{T}$ cell function was uniquely altered with combination therapy. Production of Granzyme B and IFN $\gamma$ by $\mathrm{CD}^{+}{ }^{+} \mathrm{T}$ cells was significantly improved with combination therapy versus all other treatments, including N-803 monotherapy, in the lung. Additionally, $\mathrm{CD}^{+} \mathrm{T}$ cell production of IFN $\gamma$ was similarly enhanced in primary tumor. Thus, we hypothesize that increased $\mathrm{CD}^{+} \mathrm{T}$ cell function is at least partially responsible for the enhanced anti-tumor efficacy of N-803 $+\alpha$ PD-L1 versus $\mathrm{N}-803$ monotherapy. Investigation of biomarkers of responsiveness to this combination therapy is of interest, including the role of tumor MHC Class I and PD-L1 level, capacity to mount a systemic IFN $\gamma$ response, expansion of neoantigen-reactive T cells, and TCR clonality. In both murine tumor models used in our studies, the levels of tumor MHC Class I ( 90\%) and PD-L1 (Fig. 1a) in vivo are very similar within each treatment cohort, as is their capacity to mount an IFN $\gamma$ response (Figs. 6 and 7). Future preclinical studies will examine other potential biomarkers of response, including TCR clonality.

An important reason for the combination of $\mathrm{N}-803$ and $\alpha \mathrm{PD}-\mathrm{L} 1$ in these studies was to reduce immunosuppression in the TME. This is especially relevant as we demonstrate for the first time that $\mathrm{N}-803$ induces upregulation of PD-L1 on immune cells in the primary tumor, lung, and spleen. MDSC, which are major contributors to immune suppression in the TME [39, 40], displayed an especially robust increase of PD-L1 expression. PD-L1 expression has been shown to correlate with MDSC immunosuppressive function [39-41], so it is possible that part of the enhanced anti-tumor efficacy observed with combination therapy is due to blocking PD-L1 on MDSC populations. We also observed significant reductions in G-MDSC/granulocyte populations in the lung with combination therapy. Investigating MDSC phenotype and function is of future interest.

Interestingly, while N-803 $+\alpha$ PD-L1 combination did significantly reduce $4 \mathrm{~T} 1$ lung metastasis, the combination was unable to control primary tumor growth. Given the differences observed in the immune compartments in the primary tumor, lung, and spleen, which have never before been fully interrogated and compared, we hypothesize that the mechanism by which $\mathrm{N}-803$ $+\alpha$ PD-L1 therapy alters lung tumor burden primarily occurs outside of the regulation of primary tumor growth. While there were minimal changes to immune cell infiltration and phenotype in the primary tumor, 
$\mathrm{N}-803+\alpha \mathrm{PD}-\mathrm{L} 1$ combination greatly enhanced immune cell numbers and activation in other compartments, including the lung vasculature and spleen. Thus, instead of preventing the initiation of the metastatic process, it is possible that $\mathrm{N}-803+\alpha \mathrm{PD}-\mathrm{L} 1$ treatment promotes NK and $\mathrm{CD}^{+} \mathrm{T}$ cell killing of metastasizing tumor cells. This is supported by reports showing that NK cells can mediate tumor surveillance and control through lysis of tumor cells at peripheral sites, including in the vasculature [42-44]. Furthermore, NK cells have been shown to be essential for the regulation of metastasis by promoting tumor cell killing during the epithelial to mesenchymal transition without affecting primary tumor growth [45], and NK cells have also been visualized at the invasive margin of NSCLC tumors in patients [46]. Given that NK cells were $60 \%$ of total immune cells in the vasculature after treatment with either $\mathrm{N}-803$ or $\mathrm{N}-803+\alpha \mathrm{PD}-\mathrm{L} 1$, this result may explain why NK cells were more necessary for protection against lung metastasis versus $\mathrm{CD} 8^{+} \mathrm{T}$ cells. However, this increase in NK cells alone by $\mathrm{N}-803$ was not solely responsible for the anti-tumor efficacy of $\mathrm{N}-803+\alpha \mathrm{PD}-\mathrm{L} 1$, as the addition of $\alpha \mathrm{PD}-\mathrm{L} 1$ further decreased lung tumor burden. We hypothesize that this additional efficacy is attributed to the effect that $\mathrm{CD}^{+} \mathrm{T}$ cells have on survival and growth of the metastases within the lung parenchyma, as $\mathrm{N}-803$ $+\alpha$ PD-L1 specifically increased in $\mathrm{CD}^{+} \mathrm{T}$ cell function in this compartment versus all other treatments. Inducing these same phenotypic and functional changes on $\mathrm{NK}$ and $\mathrm{CD}^{+} \mathrm{T}$ cells within the primary TME could drastically decrease primary tumor burden. While we observed $\alpha$ PD-L1 monoclonal antibody localization in the primary TME (data not shown), whether N-803 also permeates into the primary tumor remains to be determined. Escorting N-803 to the TME by altering tumor permissiveness or by adding a tumor-targeting component such as $\alpha \mathrm{PD}-\mathrm{L} 1$ to N-803 may further improve anti-tumor efficacy through in-situ activation of NK and $\mathrm{CD} 8^{+} \mathrm{T}$ cells.

\section{Conclusions}

For the first time, we demonstrate that the combination of N-803+ $\alpha$ PD-L1 therapy is well-tolerated and induces significant anti-tumor efficacy in multiple murine models of solid carcinomas that are nonand/or minimally responsive to either monotherapy. Furthermore, we evaluated the immune-associated effects of $\mathrm{N}-803+\alpha \mathrm{PD}-\mathrm{L} 1$ in multiple compartments, including the primary tumor, the lung as a site of metastasis, and spleen. We determined that this robust reduction in tumor burden is driven by NK and $\mathrm{CD}^{+} \mathrm{T}$ cells, which display an activated phenotype and greatly enhanced functionality upon N-803 $+\alpha \mathrm{PD}-\mathrm{L} 1$ treatment. These results provide the rationale for the clinical combination of N-803 with PD-L1-targeting agents for the treatment of both $\alpha \mathrm{PD}-\mathrm{L} 1-$ responsive and $\alpha$ PD-L1-refractory tumors.

\section{Additional file}

\begin{abstract}
Additional file 1: Table S1. List of flow cytometry antibodies used for analysis of murine immune cell populations. Table S2. Flow cytometry gating strategy used for identification of murine immune cell populations. Figure S1. Validation of intravascular CD45-antibody labeling for the discrimination of vascular- versus parenchymal-resident immune cells in the spleen, lung, and primary tumor. Figure S2. Dose escalation of N-803 in combination with a clinical relevant dose of aPD-L1. Figure S3. Combination of N-803+aPD-L1 reduces MC38-CEA primary tumor burden and increases survival. Figure S4. Depletion efficiency of CD8 and NK cell depletions, and requirement of $\mathrm{CD}^{+} \mathrm{T}$ cells for anti-tumor efficacy of N-803 and aPD-L1. Figure S5. CD8 ${ }^{+} \mathrm{T}$ cells and NK cells are responsible for MC38-CEA anti-tumor efficacy. Figure S6. N-803+aPD-L1 combination decreases CD4 ${ }^{+} \mathrm{T}$ cell and Treg numbers in the lung vasculature. Figure S7. N-803+aPD-L1 combination reduces G-MDSC numbers in the lung vasculature. Figure S8. N-803 monotherapy and combination of $\mathrm{N}-803+\mathrm{aPD}-\mathrm{L} 1$ promotes an activated NK cell phenotype and increases NK function. Figure S9. CD8 ${ }^{+} \mathrm{T}$ cell expression of PD-1 is significantly reduced in lung parenchyma and vasculature after $\mathrm{N}-803$ +aPD-L1 treatment. Figure S10. Combination of N-803+aPD-L1 increases effector function of $\mathrm{CD}^{+} \mathrm{T}$ cells. (PDF $554 \mathrm{~kb}$ )
\end{abstract}

\begin{abstract}
Abbreviations
6- TG: 6-Thioguanine; CEA: Carcinoembryonic antigen; DLT: Dose limiting toxicity; DP: Double producing; G-MDSC: Granulocytic myeloid derived suppressor cell; gMFl: geometric mean fluorescence intensity; i.p.: Intraperitoneal; i.t.: Intratumoral; i.v.: Intravenous; IFNY: Interferon gamma; IL: Interleukin; M-MDSC: Monocytic MDSC; mOS: median overall survival; NK: Natural killer; NSCLC: Non-small cell lung cancer; PBS: Phosphate buffered saline; PD-1: Programmed cell death-1; PD-L1: Programmed cell death ligand-1; r: Recombinant; s.C.: Subcutaneous; SP: Single producing; $\mathrm{T}_{\mathrm{CM}}$ : Central memory $T$ cell; $T_{\text {eff: }} T$ cell effector; $T_{E M}$ : Effector memory $T$ cell; TIL: Tumor-infiltrating lymphocyte; TME: Tumor microenvironment; TN: Triple negative; TNFa: Tumor necrosis factor alpha; $T_{\text {reg: }}$ : Regulatory $T$ cell; $\gamma c$ : Gamma c; $\mu \mathrm{g}$ : Microgram; $\mu$ : Microliter
\end{abstract}

\section{Acknowledgements}

The authors thank Curtis Randolph for excellent technical assistance; Yanyu Wang, Sara Loftus, and Ludmila Krymskaya (Clinical Support Laboratory, Frederick National Laboratory for Cancer Research, Leidos Biomedical Research, Inc.) for their technical support; and Debra Weingarten for her assistance in the preparation of this manuscript.

\section{Funding}

This research was supported by the Intramural Research Program of the Center for Cancer Research, National Cancer Institute (NCI), National Institutes of Health, and by a Cooperative Research and Development Agreement (CRADA) between the $\mathrm{NCl}$ and NantBioScience.

\section{Availability of data and materials}

The data generated and analyzed will be made from the corresponding author on reasonable request.

\section{Authors' contributions}

Designing of research studies: KMK, SRG, and JS; Conducting experiments: KMK, KCH, SRG; Acquiring data: KMK, KCH; Preclinical, manufacturing, and clinical development of N-803: SA; Analyzing data: KMK, SRG; Writing the manuscript: KMK, SRG. All authors read and approved the final manuscript.

Ethics approval and consent to participate

All in vivo experiments were approved by the $\mathrm{NCl} / \mathrm{NIH}$ Animal Care and Use Committee (ACUC). 


\section{Consent for publication}

Not applicable.

\section{Competing interests}

Authors from the National Cancer Institute do not have any competing interests to disclose. S.A. is an employee and shareholder of Altor Bioscience (a NantWorks company).

\section{Publisher's Note}

Springer Nature remains neutral with regard to jurisdictional claims in published maps and institutional affiliations.

\section{Author details}

${ }^{1}$ Laboratory of Tumor Immunology and Biology, Center for Cancer Research, National Cancer Institute, National Institutes of Health, Bethesda, MD, USA.

${ }^{2}$ Altor Bioscience, a NantWorks company, Miramar, FL, USA.

\section{Received: 16 October 2018 Accepted: 27 February 2019}

Published online: 21 March 2019

\section{References}

1. Waldmann TA. Cytokines in cancer immunotherapy. Cold Spring Harb Perspect Biol. 2018;3(10):2

2. K-p H, Zhu X, Liu B, Jeng E, Kong L, Yovandich JL, et al. IL-15:IL-15 receptor alpha superagonist complex: high-level co-expression in recombinant mammalian cells, purification and characterization. Cytokine. 2011;56(3): 804-10.

3. Zhu X, Marcus WD, Xu W, Hi L, Han K, Egan JO, et al. Novel human Interleukin15 agonists. J Immunol. 2009;183(6):3598-607.

4. Xu W, Jones M, Liu B, Zhu X, Johnson CB, Edwards AC, et al. Efficacy and mechanism-of-action of a novel superagonist interleukin-15: interleukin-15 receptor aSu/fc fusion complex in syngeneic murine models of multiple myeloma. Cancer Res. 2013;73(10):3075-86.

5. Rhode PR, Egan JO, Xu W, Hong H, Webb GM, Chen X, et al. Comparison of the superagonist complex, ALT-803, to IL15 as cancer immunotherapeutics in animal models. Cancer Immunol Res. 2016:4(1):49-60.

6. Conlon KC, Lugli E, Welles HC, Rosenberg SA, Fojo AT, Morris JC, et al. Redistribution, hyperproliferation, activation of natural killer cells and CD8 T cells, and cytokine production during first-in-human clinical trial of recombinant human Interleukin-15 in patients with cancer. J Clin Oncol. 2015;33(1):74-82.

7. Romee R, Cooley S, Berrien-Elliott MM, Westervelt P, Verneris MR, Wagner JE, et al. First-in-human phase 1 clinical study of the IL-15 superagonist complex ALT-803 to treat relapse after transplantation. Blood. 2018; 131(23):2515-27.

8. Margolin K, Morishima C, Velcheti V, Miller JS, Lee SM, Silk AW, et al. Phase I trial of ALT-803, a novel recombinant Interleukin-15 complex, in patients with advanced solid tumors. Clin Cancer Res. 2018;24(22):5552-61.

9. Kim PS, Kwilas AR, Xu W, Alter S, Jeng EK, Wong HC, et al. IL-15 superagonist/ IL-15RaSushi-fc fusion complex (IL-15SA/IL-15RaSu-fc; ALT-803) markedly enhances specific subpopulations of NK and memory CD8+ T cells, and mediates potent anti-tumor activity against murine breast and colon carcinomas. Oncotarget. 2016;7(13):16130-45.

10. Mathios D, Park C-K, Marcus WD, Alter S, Rhode PR, Jeng EK, et al Therapeutic administration of IL-15 superagonist complex ALT-803 leads to long-term survival and durable antitumor immune response in a murine glioblastoma model. Int J Cancer. 2016;138(1):187-94.

11. Liu $B$, Jones $M$, Kong $L$, Noel $T$, Jeng EK, Shi $S$, et al. Evaluation of the biological activities of the IL-15 superagonist complex, ALT-803, following intravenous versus subcutaneous administration in murine models. Cytokine. 2018;107:105-12

12. Postow MA, Callahan MK, Wolchok JD. Immune checkpoint blockade in cancer therapy. J Clin Oncol. 2015;33(17):1974-82.

13. Zou W, Wolchok JD, Chen L. PD-L1 (B7-H1) and PD-1 pathway blockade for cancer therapy: mechanisms, response biomarkers, and combinations. Sci Transl Med. 2016:8:328rv4.

14. Hamanishi J, Mandai M, Iwasaki M, Okazaki T, Tanaka Y, Yamaguchi K, et al. Programmed cell death 1 ligand 1 and tumor-infiltrating CD8+ T lymphocytes are prognostic factors of human ovarian cancer. Proc Natl Acad Sci U S A. 2007;104(9):3360-5.
15. Qing Y, Li Q, Ren T, Xia W, Peng Y, Gl L, et al. Upregulation of PD-L1 and APE1 is associated with tumorigenesis and poor prognosis of gastric cancer Drug Des Devel Ther. 2015;9:901-9.

16. Robert C, Schachter J, Long GV, Arance A, Grob JJ, Mortier L, et al. Pembrolizumab versus ipilimumab in advanced melanoma. N Engl J Med. 2015:372(26):2521-32.

17. Topalian SL, Sznol M, McDermott DF, Kluger HM, Carvajal RD, Sharfman WH, et al. Survival, durable tumor remission, and long-term safety in patients with advanced melanoma receiving nivolumab. J Clin Oncol. 2014;32(10): 1020-30.

18. Carbone DP, Reck M, Paz-Ares L, Creelan B, Horn L, Steins M, et al. First-line nivolumab in stage IV or recurrent non-small-cell lung cancer. New Eng J Med. 2017:376(25):2415-26.

19. Borghaei H, Paz-Ares L, Horn L, Spigel DR, Steins M, Ready NE, et al. Nivolumab versus docetaxel in advanced nonsquamous non-small-cell lung cancer. New Eng J Med. 2015;373(17):1627-39.

20. Bellmunt J, de Wit R, Vaughn DJ, Fradet $Y$, Lee J-L, Fong $L$, et al. Pembrolizumab as second-line therapy for advanced urothelial carcinoma. New Eng J Med. 2017; 376(11):1015-26.

21. Apolo AB, Infante JR, Balmanoukian A, Patel MR, Wang D, Kelly $K$, et al. Avelumab, an anti-programmed death-ligand 1 antibody, in patients with refractory metastatic urothelial carcinoma: results from a multicenter, phase lb study. J Clin Oncol. 2017;35(19):2117-24.

22. Kinter AL, Godbout EJ, McNally JP, Sereti I, Roby GA, O'Shea MA, et al. The common gamma-chain cytokines IL-2, IL-7, IL-15, and IL-21 induce the expression of programmed death-1 and its ligands. J Immunol. 2008; 181(10):6738-46.

23. Wrangle JM, Velcheti V, Patel MR, Garrett-Mayer E, Hill EG, Ravenel JG, et al. ALT-803, an IL-15 superagonist, in combination with nivolumab in patients with metastatic non-small cell lung cancer: a non-randomised, open-label, phase 1b trial. Lancet Oncol. 2018;19(5):694-704

24. Clarke P, Mann J, Simpson JF, Rickard-Dickson K, Primus FJ. Mice transgenic for human carcinoembryonic antigen as a model for immunotherapy. Cancer Res. 1998:58(7):1469-77.

25. Robbins PF, Kantor JA, Salgaller M, Hand PH, Fernsten PD, Schlom J. Transduction and expression of the human carcinoembryonic antigen gene in a murine colon carcinoma cell line. Cancer Res. 1991;51(14): 3657-62.

26. Pulaski BA, Ostrand-Rosenberg S. Mouse 4T1 breast tumor model. Curr Protoc Immunol. 2001; Chapter 20:Unit 20.2. https://doi.org/10.1002/ 0471142735.im2002s39. PMID: 18432775.

27. Ardiani A, Gameiro SR, Palena C, Hamilton DH, Kwilas A, King TH, et al. Vaccine-mediated immunotherapy directed against a transcription factor driving the metastatic process. Cancer Res. 2014;74(7):1945-57.

28. Anderson KG, Mayer-Barber $K$, Sung H, Beura L, James BR, Taylor JJ, et al. Intravascular staining for discrimination of vascular and tissue leukocytes. Nat Protoc. 2014:9(1):209-22.

29. Pulaski BA, Ostrand-Rosenberg S. Reduction of established spontaneous mammary carcinoma metastases following immunotherapy with major histocompatibility complex class II and B7.1 cell-based tumor vaccines. Cancer Res. 1998:58(7):1486-93.

30. Sagiv-Barfi I, Kohrt HE, Czerwinski DK, Ng PP, Chang BY, Levy R. Therapeutic antitumor immunity by checkpoint blockade is enhanced by ibrutinib, an inhibitor of both BTK and ITK. Proc Natl Acad Sci U S A. 2015;112(9):E966-72.

31. Ouzounova M, Lee E, Piranlioglu R, El Andaloussi A, Kolhe R, Demirci MF, et al. Monocytic and granulocytic myeloid derived suppressor cells differentially regulate spatiotemporal tumour plasticity during metastatic cascade. Nat Commun. 2017:8:1-13.

32. Liu Z, Kim JH, Falo J, Louis D, You Z. Tumor regulatory T cells potently abrogate antitumor immunity. J Immunol. 2009;182(10):6160-7.

33. Spranger S, Luke JJ, Bao R, Zha Y, Hernandez KM, Li Y, et al. Density of immunogenic antigens does not explain the presence or absence of the Tcell-inflamed tumor microenvironment in melanoma. Proc Natl Acad Sci U S A. 2016;113(48):E7759-E68.

34. Sharma P, Hu-Lieskovan S, Wargo JA, Ribas A. Primary, adaptive and acquired resistance to cancer immunotherapy. Cell. 2017;168(4):707-23.

35. Mall C, Sckisel GD, Proia DA, Mirsoian A, Grossenbacher SK, Pai CS, et al. Repeated PD-1/PD-L1 monoclonal antibody administration induces fatal xenogeneic hypersensitivity reactions in a murine model of breast cancer. Oncoimmunology. 2016;5(2):e1075114. 
36. Hesker PR, Krupnick AS. The role of natural killer cells in pulmonary immunosurveillance. Front Biosci (Schol Ed). 2013;5:575-87.

37. Al Omar SY, Marshall E, Middleton D, Christmas SE. Increased killer immunoglobulin-like receptor expression and functional defects in natural killer cells in lung cancer. Immunology. 2011;133(1):94-104.

38. Yang Q, Goding SR, Hokland ME, Basse PH. Antitumor activity of NK cells. Immunol Res. 2006;36(1-3):13-25.

39. Ballbach M, Dannert A, Singh A, Siegmund DM, Handgretinger R, Piali L, et al. Expression of checkpoint molecules on myeloid-derived suppressor cells. Immunol Lett. 2017;192:1-6.

40. Lu C, Redd PS, Lee JR, Savage N, Liu K. The expression profiles and regulation of PD-L1 in tumor-induced myeloid-derived suppressor cells. Oncolmmunology. 2016;5(12):1-13

41. Youn J-I, Nagaraj S, Collazo M, Gabrilovich DI. Subsets of myeloid-derived suppressor cells in tumor-bearing mice. J Immunol. 2008;181(8):5791-802.

42. Diefenbach A, Jensen ER, Jamieson AM, Raulet DH. Rae1 and H60 ligands of the NKG2D receptor stimulate tumour immunity. Nature. 2001;413:165.

43. Malladi S, Macalinao DG, Jin X, He L, Basnet H, Zou Y, et al. Metastatic latency and immune evasion through autocrine inhibition of WNT. Cell. 2016;165(1):45-60.

44. Spiegel A, Brooks MW, Houshyar S, Reinhardt F, Ardolino M, Fessler E, et al. Neutrophils suppress intraluminal NK cell-mediated tumor cell clearance and enhance extravasation of disseminated carcinoma cells. Cancer Discov. 2016;6(6):630.

45. Chockley PJ, Chen J, Chen G, Beer DG, Standiford TJ, Keshamouni VG. Epithelial-mesenchymal transition leads to NK cell-mediated metastasisspecific immunosurveillance in lung cancer. J Clin Invest. 2018;128(4): 1384-96.

46. Platonova S, Cherfils-Vicini J, Damotte D, Crozet L, Vieillard V, Validire $P$, et al. Profound coordinated alterations of intratumoral NK cell phenotype and function in lung carcinoma. Cancer Res. 2011;71(16):5412-22.

Ready to submit your research? Choose BMC and benefit from:

- fast, convenient online submission

- thorough peer review by experienced researchers in your field

- rapid publication on acceptance

- support for research data, including large and complex data types

- gold Open Access which fosters wider collaboration and increased citations

- maximum visibility for your research: over $100 \mathrm{M}$ website views per year

At $\mathrm{BMC}$, research is always in progress.

Learn more biomedcentral.com/submissions 